\title{
SLA AND THE EMERGENCE OF CREOLES
}

\author{
Salikoko S. Mufwene \\ University of Chicago
}

\begin{abstract}
Although the emergence of creoles presupposes naturalistic SLA, current SLA scholarship does not shed much light on the development of creoles with regard to the population-internal mechanisms that produce normalization and autonomization from the creoles' lexifiers. This is largely due to the fact that research on SLA is focused on individuals rather than on communities of speakers producing their own separate norms, whereas genetic creolistics deals precisely with this particular aspect of language change and speciation. It is not enough to prove that transfer from the first to the second language is possible and can evolve into substrate influence on the emergent vernaculars - transfer is not ineluctable and varies from one learner to another. Additionally, how and why particular features of some speakers spread to a whole population (or to parts thereof), whereas others do not, must be accounted for. Consistent with colonial socioeconomic history, the gradual emergence of creoles suggests a complex evolution that cannot be accounted for with simplistic invocations of either interlanguage or relexification. This article presents limitations in the cross-pollination that has been expected from genetic creolistics and research on SLA.
\end{abstract}

The number of studies that connect research on the emergence of creoles to research on SLA has increased remarkably over the past two

I am grateful to Enoch Aboh, Michel DeGraff, Cécile B. Vigouroux, and four anonymous $S S L A$ reviewers for very constructive comments on previous versions of this article. I also thank Albert Valdman and his editorial staff for their relenting patience in waiting for this essay since it was first commissioned in 2005. I have made every effort to compensate for the long delay by factoring in the latest relevant literature I am aware of and even to become more critical of the 1990 state-of-the-art article that the present essay was expected to update. I am solely responsible for the remaining shortcomings.

Address correspondence to: Salikoko S. Mufwene, University of Chicago, Department of Linguistics, 1010 E. 59th Street, Chicago, IL 60637; e-mail: s-mufwene@uchicago.edu. 
decades; this is especially true of publications that claim that SLA can inform genetic creolistics-the study of the emergence of creoles. ${ }^{1}$ Taking as a convenient reference point, the publication of "Transfer and the Substrate Hypothesis in Creolistics" (Mufwene, 1990), a number of interesting books have been authored or edited that deal with this subject matter, at least in passing, such as Cook (1993), Mufwene (1993b), Ellis (1994), DeGraff (1999), Leather and van Dam (2003), Winford (2003), Lefebvre, White, and Jourdan (2006b), Ansaldo, Matthews, and Lim (2007), Michaelis (2008a), Siegel (2008a), and Kouwenberg and Singler (2009). The list of publications becomes even longer when individual essays are included.

Lefebvre et al.'s (2006b) edited volume is worth singling out not only because of its title but also because it contains several chapters that seek to shed light on the nature of the connection between some processes involved in SLA, especially the processes that produce interlanguages and that lead to the emergence of creoles. This volume also includes an informative historical survey, by Siegel (2008a), of the connection between the two research areas, which very aptly complements Mufwene (1990) and to which the present article will not attempt to add much, except regarding later publications. The addition is more obvious in the critique of the expected benefits from the connections between research on SLA and on creoles. This article is devoted more usefully to issues that arise from these recent publications, which generally claim or appear to be better informed about both SLA and the emergence of creoles and which definitely support substrate influence on structures of these vernaculars. In addition to Lefebvre et al. (2006b), the current article focuses particularly on a special issue of SSLA entitled "Reconsidering the Role of SLA in Pidginization and Creolization" (Kouwenberg \& Patrick, 2003) and on the work of Aboh (e.g., 2006), Mather (2006), Siegel (2008a, 2009), Michaelis (2008a), and Plag (2008, 2009).

The increasing number of publications that invoke a generative approach and claim more explanatory power is also noteworthy. It is not obvious that these publications are really more empirically grounded or account for the facts more accurately than others. For instance, Sprouse (2006) and Schwartz (2006) claimed that their full transfer/full access hypothesis accounts more adequately for SLA than alternative hypotheses and allegedly in the same way that Lefebvre's $(1998,2004)$ relexification hypothesis (RH) does for creole genesis. Interestingly, some practitioners of the generative approach have justifiably disputed the RH (e.g., Aboh, 2006, 2007, 2009; Bickerton, 1984, 1999; DeGraff, 2002, 2009). In the present review, the focus is more on accounts of facts; interested readers can reinterpret these observations in the language of their preferred theoretical framework. These frameworks can be seen as different languages - that is, as means of communication that merely 
give a voice to the substance of the arguments but that should not be overrated at the expense of the arguments.

A wide range of issues arise from how research on SLA and on the development of creoles can inform each other: (a) What does the term language acquisition really mean and what does this particular interpretation entail for the comparison of the two research areas? (b) How do learners set the parameters of their approximations of the target language (TL) and how is the process in SLA different from that in the development of competence in the mother tongue? In the first place, what is a realistic interpretation of parameter setting from a language emergence perspective, which is assumed in this article? (c) Do adult second-language (L2) learners still have access to Universal Grammar (UG)? Would adults be able to speak, let alone learn another language, without UG as infrastructure? (d) Does guided, instruction-based SLA hold the same potential to inform research on the emergence of creoles as naturalistic SLA, in which the learner has to work out their approximations of the TL's system on their own? ${ }^{2}$ (e) Is it justified to compare the emergence of creoles, which is a populationwide process, with language acquisition—an individual learner's activity—simply because creole emergence depends partly on how acquisition proceeds?

There are many other related questions that need not be articulated yet at this point. The current article will address all of these questions, seizing the opportunity to correct some of the positions adopted in Mufwene (1990). For instance, DeGraff (1999, 2009) has convincingly demonstrated how mistaken it is to assume that creoles have been shaped exclusively either by children or by adults alone. Neither position is entailed by the hypothesis that creoles emerged gradually, which is assumed here. Everybody, regardless of age, must have made their own selections from their interaction feature pool (Siegel's, 2008a, pool of variants), which included features that originated outside the lexifier. It is through the action of the invisible hand, with which the social process that Chaudenson (e.g., 2001) identified as normalization must be associated, that communal norms arise from the verbal interactions of individual speakers (Mufwene, 2005a, 2008). Note that normalization as the emergence of communal norms does not preclude variation, which is consistent with the position that creoles, like other natural languages, are emergent phenomena in constant search, so to speak, for equilibria.

In the present article, some of these questions are grouped and addressed together. The major topics addressed here include the meaning of the term language acquisition, the emergence of creoles, the connection between SLA and the emergence of creoles, and some conclusions. However, a couple of caveats that justify the particular approach taken here should be presented first. The reader should bear in mind that the purpose of this article is not to summarize SLA scholarship. The focus 
here is on literature that has claimed that findings on SLA can shed light on the emergence of creoles. Basic knowledge of SLA and the emergence of creoles is used to critique this literature and provides an assessment of what has happened since Mufwene (1990). At times, current knowledge will call for the revision of positions that Mufwene embraced.

\section{SOME CAVEATS}

It is assumed here that the term creole is most usefully applied only to vernaculars that developed in plantation settlement colonies out of the contact of European and non-European languages between the 17th and the 18th centuries (Mufwene, 1997). This characterization thus differs from that of Siegel (2008a, 2009), for instance, who extended the term to the expanded pidgins of the Pacific and in fact treated these pidgins and Hawaiian English Creole as epistemic creole prototypes-that is, those that have shaped the conceptualization of these vernaculars. The Pacific islands were colonized differently from the Caribbean and the Indian Ocean, which have provided epistemic prototypes and for which the term creole was first used in colonial history (Mufwene, 2005a, 2008).

It is for want of a better term that lexifier is used in this article in reference to the European languages from which creoles have evolved. Many of the working assumptions associated with this term are questionable. For instance, it is doubtful that anybody can learn a language naturalistically by memorizing its vocabulary without attention to any of the morphosyntactic and semantic constraints associated with the relevant words-although learning by inference through interactions with speakers of the TL is imperfect. Works on SLA such as Martohardjono and Flynn (1995) spoke against such an assumption.

Other assumptions that underlie the term lexifier are questioned by the socioeconomic histories of the territories in which creoles evolved (Chaudenson, 1992, 2001, 2003; Mufwene, 2001, 2005a, 2008). In fact, it is not accurate to claim that only French creoles developed directly from their European lexifiers. Although Siegel (2008a, 2009) made this claim, he has not shown what particular interactive conditions would have favored the emergence of pidgins on the homesteads of plantation settlement colonies in which English, Portuguese, and Dutch creoles emerged. This is not to say that no full-fledged languages have emerged from antecedent pidgins-there exist expanded pidgins with structures as complex as those of creoles. However, creoles are defined more by the socioeconomic histories of their emergence than by their structures (Mufwene, 2000). The fact that creoles result from different contact histories than those that lead to expanded pidgins highlights the significance of history in helping to decide whether a bottle is half empty 
or half full. The outcomes may be similar, but the evolutionary trajectories are not necessarily the same.

Additionally, although the colonial koinés that emerged out of the contacts of metropolitan dialects of the same language and were targeted by the populations that produced creoles were internally variable and changed structurally from the earlier to the later stages of colonization, this should not be interpreted as absence of a TL. For that matter, interidiolectal variation in any population in which a language is acquired natively could also be thought to provide no TL. What Chaudenson (e.g., 1979) characterized as approximations of approximations appears to be basically the same idea reformulated rather inaccurately by Baker $(1990,1996)$, Becker and Veenstra (2003), Kouwenberg (2006), and Mather (2006) as target shift, as these authors also suggested that the transition was an abrupt event. It is clear that several intermediate states must have been involved in the protracted evolution from the original koinés to the modern basilects, the varieties most different from the standard dialects and usually identified almost exclusively as creoles. What Chaudenson (e.g., 1992) sought to capture is that, during the plantation phase, model speakers for the Bozal slaves who had just arrived from Africa were often seasoned, rather than Creole, slaves-that is, African-born slaves who had arrived earlier, had been acculturated, and were more experienced L2 speakers of the colonial vernacular, which had been learned either from Creole slaves (perhaps of the homestead phase) or other, earlier seasoned slaves. The learning chain produced approximations of approximations of the TL, which thus consisted of a wide range of varieties, both native and nonnative.

The term target shift is a distortion of how the linguistic situation appears to have evolved, probably in ways not too different from the more recent indigenization of European colonial languages in Asia and Africa-except that the TL varieties were scholastic in the cases of Asia and Africa and the acquisition process has generally been tutored (Mufwene, 2009a). From an evolutionary perspective, the term lexifier is a historical oxymoron and is maintained here only for lack of an adequate short alternative. From the point of view of language learning, the relevant languages are sometimes identified as TLs.

As in Baker (1990), the issue seemed to be misapprehended by Siegel (2008a) when he argued that "there is not really a target language as such [where creoles developed], because the goal is not grammatical acquisition but communication" (p. 122). Although all of the parties involved were interested in communicating with each other, they appear to have known that it would be easier to use an extant language, under the constraints of the contact situation, than to create one from scratch, so to speak. The socioeconomic structure also made it impossible for them to disregard the European colonial language. 
The relevant colonial history also makes it unlikely that the slaves designed the putative means of interethnic communication hypothesized by Baker (1997) as a solution of their communication problem. Like other modern language varieties, creoles are emergent phenomena. From an ethnographic perspective, creoles are accidental outcomes of language shift in extensive multilingual settings, in which it was obvious that some languages were socioeconomically dominant or more useful and thus needed to be targeted. The evidence shows that the overwhelming part of the vocabulary typically originates in the language in which the economy developed, although this was also the language of oppression. Grammar is not independent of the properties of lexical items and is in fact an ensemble of generalizations over the behavior of these lexical items in different contexts (Bolinger, 1973). Although there is widespread evidence for assuming learning with modification, the same evidence also speaks in favor of one particular language prevailing as the TL. It is interesting to note that Siegel (2009) seems to admit the existence of a TL in such contact settings.

It should be pointed out that genetic creolistics reflects normal restructuring and speciation processes that can be observed in the evolution of any language (Mufwene, 2001, 2005a, 2008). The use of the term genesis has been deliberately avoided in the title of the present article because the evolutionary relevance of creoles does not stop with their origins. Indeed, those who use the term target shift appear to have had a similar gradualist perspective, which alludes to a phase during which a significant proportion of learners of the colonial vernacular no longer targeted the variety to which the homestead-phase slaves had been exposed but a new variety that was already divergent. Thus, it can be argued that this evolution did not come to term until the 19th century, after the abolition of the slave trade or even after the importation of contract laborers once the slaves had been emancipated. The evolutionary discourse avoided here would make sense only to the extent that it is also mistakenly assumed that today's speakers of these vernaculars keep their systems intact and no longer contribute to the development of novel structures. Although disputable, the literature about the supposed decreolization as debasilectalization of creoles speaks for the continuous evolution of the structures of creoles, as of any modern language.

The term creolization is generally avoided because it is not evident that there are any evolutionary processes, or combinations thereof, that are specific to creoles (e.g., Mufwene, 2000). Furthermore, there are no systemic changes that are not externally motivated. This position too should become obvious in the present article, although, due to space limitations, the reader will sometimes be referred to other publications in which the matter is discussed in detail. 


\section{LANGUAGE ACQUISITION AS A CONSTRUCTION PROCESS}

Linguists have traditionally subscribed to the assumption that languages are systems that consist of various kinds of units and rules. Languages are sometimes discussed as though, like social institutions, they were external to their speakers and could exist independently. It is assumed that native speakers not only acquire languages as welldefined and integrated entities but also keep them intact for transmission to the next generation of speakers. Thus, the changes that noncreole languages undergo normally or naturally would seem to be the result of the internal dynamics of their systems rather than the agency of their speakers. The putatively anomalous changes traditionally associated with creoles would exceptionally be due to external motivation, associated with language contact, which brought systems to compete with each other. In this case, the modifications are allegedly so severe that the emergent vernaculars had to be disenfranchised as separate languages and have been denied genetic links to their lexifiers (Thomason, 2001; Thomason \& Kaufman, 1988).

From the point of view of language learning, the usual explanation invoked has been imperfect language acquisition or learning, although, as noted by Lass (1997) as well as other linguists (e.g., Holm, 1988; Thomason \& Kaufman, 1988; Wekker, 1996), there is no perfect replication even in first-language (L1) acquisition. As a matter of fact, the relevant literature has hardly paused to explain whether, from a diachronic or developmental perspective, transmission must be understood as in evolutionary biology and acquisition compared to inheritance of genes. Reality suggests otherwise. Assuming naturalistic learning, there is language transmission only to the extent that speakers in the learner's social environment produce utterances associated with a particular language, the so-called primary linguistic data (PLD), and that the learner infers how to interpret these utterances and how to produce utterances that can in turn be understood by those with whom he or she interacts. Developing any level of such competence is what language acquisition amounts to; the language learner-unlike animal offspring in biology, which passively inherit their parents' genes-must work, however effortlessly, to acquire language.

According to Meillet (1929) and Hagège (1993), language acquisition involves both inheritance and recreation, which DeGraff $(1999,2009)$ and Mufwene (2001, 2005a) have identified as a (re)construction process, in which the learner selectively integrates materials copied from various model speakers into his or her own idiolect. This emergent speaker variety replicates that of neither parent nor of any other speaker. As Wolfram (2000) clearly showed, every speaker's idiolect reflects his or her own history of social interactions, from home to adult 
and professional life, going through the daycare and school experience with teachers and various classmates that have selectively influenced the speaker. It is not just children of immigrants that do not speak like their parents. Nobody speaks exactly like anybody else, because nobody's history of social interactions is like that of anybody else, even among members of the same family, except perhaps for conjoined twins. Language transmission is thus both vertical and horizontal (Mufwene, 2001). In fact, it appears that language transmission is primarily horizontal because, unlike in biological transmission, social interaction matters more than the age of the population that makes the PLD available. Moreover, population structure determines who the learner is most likely to interact with; age-grading plays a more important role after the child joins play groups or starts school.

That no idiolect is identical to another is a function of the heterogeneity of the feature pool from which every learner selects materials that gradually shape his or her idiolect. It is not evident either that learners seek to consciously develop linguistic systems, because the main concern is communicating rather than analyzing PLD from which units and rules are inferred. Given that, in naturalistic language learning, the analysis is done tacitly, it is doubtful that learners proceed like linguists, who would constantly revise current hypotheses because of new data that call for more adequate statements of significant generalizations (McCawley, 1976). It is more likely that learners proceed analogically, capturing various partial resemblances among items and thus some small-scale generalizations, correcting errors with the help of (indirect) feedback from other speakers, and developing communicative habits until behavior in the TL becomes more or less instinctive. Knowledge of the L1 differs fundamentally from that of the L2 in how closely a speaker approximates the average speaker of the TL.

Language acquisition can be characterized as the emergence of particular communicative patterns, just like emergent phenomena in physics or economics. The patterns can be captured with rules or constraints but need not be of the same nature as in linguists' formulations. Rules and constraints are parts of the models that linguists develop to account for linguistic behavior (Mufwene, 2005a, 2008).

Universal Grammar (Chomsky, 1986) or the language bioprogram (e.g., Bickerton, 1981) certainly plays a role in the language learning process, guiding the learner's inferences so that he or she can communicate in something that is recognized as language. However, as pointed out by Martohardjono and Flynn (1995), UG is complemented by other human abilities, such as the capacity to make inferences from the lexical materials acquired during the learning process. Because language learning proceeds by inferences from different inputs, the emergent idiolect hardly replicates a single model idiolect; it instantiates what Deacon (1997) characterized as transmission error. UG just guarantees 
that the system that emerges from the new speaker's communicative practice is interpretable by other speakers or signers. An idiolect reflects the speaker-learner's individual interactive history, learning skills, and other aspects of the ecology of the acquisition process, such as whether he or she is influenced by previously learned languages (see, for instance, Helms-Park, 2003, regarding the use of knowledge from any previously acquired language while learning the TL, and Flynn, Foley, and Vinnitskaya, 2004, regarding the cumulative-enhancement model of language acquisition). Thus, UG is in some ways like the underlying machine language that enables a computer to function, which includes learning a variety of tasks it is programmed to do. UG is accessible to learners of all ages (Martohardjono \& Flynn), although it wears out with age.

However, because language learning proceeds gradually, parameter setting cannot be abrupt. It is misleading to think of parameter setting in the same way as switching power on or off (Perdue, 1995). Even the shift from a Spanish pro-drop to a pro-retention system during the acquisition of English or French is gradual and includes a transitional phase during which, although the learner makes an effort to express the subject overtly, it is nevertheless sometimes omitted. Assuming that the idiolect is truly an emergent system (Lantolf \& Thorne, 2006), it can only develop gradually, affecting (aspects of) different parameters at different times. The parameters may in fact need to be (partially) reset several times during the acquisition process.

From the perspective of pattern emergence in complexity theory, according to which systems are always in flux and in search of equilibria and self-organization (e.g., Dooley, 1997; Mikulecky, 2001), it can in fact be argued that the learner does not literally set parametric values in the way the values of a computer program would be set to have it work properly but rather that the system that emerges as a speaker's idiolect reflects his or her assessment of how things are expressed in the TL, including particular patterns of variation. For instance, where the adjective must be placed in relation to the head noun (i.e., when it can or must precede or follow), when the copula is required before a nonverbal predicate and when it is not, whether question formation involves fronting the interrogative word alone or the larger constituent that immediately contains it, and whether $w h$-movement must pied-pipe or strand a preposition of which the relative noun phrase (NP) is the object.

Thus, parameter setting does not appear to be a conscious process. UG works as a filter that guarantees that the emergent system is consistent with some of the typological options in the world's languages (Mufwene, 2001). In other words, it is a human genetic endowment that enables some approximation of the TL while producing deviations attested in some other language, not necessarily the substrate. The 
options available to the learner increase in those settings where he or she is exposed to varieties (languages or dialects) that are typologically different. UG does not preclude typological mixing, as is indeed obvious from the systems of current languages (Mufwene, 1992b). In the case of English, for example, there is variation between preposition stranding and pied-piping, dative shift versus direct-indirect object constituent order, and subject-auxiliary inversion versus no inversion, among many other phenomena. When the learner already knows another language, some of this language's settings may naturally be consistent with those of the TL and perhaps facilitate the learning process. These settings may also deviate from some TL structures; whether this leads to deviations depends largely on what the learner perceives as similarities or differences (Perdue, 1995; Véronique, 1994). According to Pienemann (2003), it depends on how the learner processes the input.

One thing that the scholarship in variationist linguistics makes obvious is that a certain amount of typological variation or mixing is acceptable in a language. This variation suggests that parameters need not be expected to be set rigidly in any idiolect, and it may be pointless to invoke a coexistent system explanation (Labov, 1998) to account for the apparent mixing of grammars in varieties such as African American vernacular English, such as whether the copula is used or omitted in utterances like he('s) tall. The nonmonolithism proposed by Mufwene (1992b), for which parameters can be set in overlapping, nonexclusive terms for part (but not all) of the relevant materials, can account as much for this variation in African American vernacular English as for the alternation exhibited in the standard French constructions provided in (1). ${ }^{3}$

(1) a. With subject-verb inversion

le livre dont nous a parlé Anne

the book about-which us has spoken Anne

b. Without subject-verb inversion

le livre dont Anne nous a parlé
the book about-which Anne us has spoken
The book that Anne told us about."

These examples demonstrate one of the ways in which selection resolves competition in language acquisition, just as in language evolution-not always in exclusive terms but very often by simply reducing the extent of variation and making one of the remaining competing parametric options dominant. Such appears to be the case with relative clauses in English, which can begin either with a relative pronoun or with a complementizer (that or null). When the relative NP is the object of a preposition, this can either be pied-piped with the relative pronoun or remain stranded, which is the only option when the 
clause starts with a complementizer (that or zero). Thus, one may hear, or at least read, any of the alternatives given in (2).

(2) a. That is the man (that) Mary went out with.

b. * That is the man with (that) Mary went out.

c. That is the man who Mary went out with.

d. That is the man with whom Mary went out.

Data from spoken English suggest that the complementizer option, also attested in written English, is the dominant one, along with the preposition stranding option, which is the only option in English creoles. The overall reality about language acquisition and language evolution is that they proceed by competition and selection among the variants available to the learner in the PLD (e.g., Mufwene, 2001)—that is, between alternative words (e.g., spade vs. shovel or pail vs. bucket), between al-

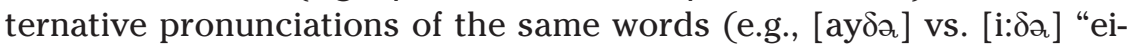
ther" or [pə'li:s] vs. ['pouli:s] "police"), and between morphosyntactic strategies for expressing the same meanings (e.g., who did it ? vs. who done it? or he was fired vs. they fired him).

Kretzschmar and Tamasi (2003) and Shackleton (2005) showed that languages as species or populations of idiolects have long-lasting memories in preserving variation, including variants that have very low statistical frequencies. This is an indication that, despite populationwide trends, learners will acquire the variants produced the most around them, even if these variants fall in the minority at the communal language level. Stigmatized variants persist simply because for speakers of the relevant varieties, these variants are the most natural forms of expression, in the sense of showing no affectation.

Community-internal homeostatic pressures account for why stigmatized nonstandard language varieties such as Gullah and Appalachian English have not yet disappeared, given that children raised in the relevant communities select the variants that speakers around them tend to use the most frequently. Such facts raise questions about invocations of universally determined markedness values (e.g., Siegel, 2008a; Thomason \& Kaufman, 1988) to account for the options that learners select. However, it is the specific ecology in which a language (variety) evolves or is learned that determines which options are marked or unmarked, and, in some cases, which ones are more (or less) marked (Mufwene, 1991, 2001).

Note that the markedness values of typologically competing options often vary from one language (variety) to another. This is precisely the reason why Michaelis (2008b) need not have invoked "the world-wide distribution of features" (p. 248). Humans are not born with some knowledge of all the typological options for each parameter; otherwise the same unmarked options would always be selected, unless some 
humans are to be considered less rational. Although learners can innovate beyond the available options, the focus here should be on articulating the particular factors that determine the markedness values relative to the settings in which language contact takes place and in which competition arises both between language varieties and between the options available on different parameters. Included in these factors are those that Siegel (2008a, 2009) surprisingly discussed as alternative constraints to markedness.

Helms-Park (2003) argued that, in some cases, markedness considerations do not even apply, particularly when the (beginning) learner does not know what the parametric options are in the TL and resorts to compensatory strategies from the L1, or any other language that he or she knows. From an ecological perspective, the correction is that not knowing the options available in the TL and resorting to an option in the L1 is still a situation of competition and selection. In the learner's mind, all of these alternatives are part of the language contact feature pool.

The question remains why some variants nonetheless become marginal (and marked). Another question is how populationwide patterns emerge, despite the fact that language acquisition is an individualbased process (Aboh, 2009; Mufwene, 2008). A more relevant question is how some variants spread to become populationwide traits but others do not. The answer lies in selection, which operates through the mutual accommodations made among members of a population. Despite age-related differences in the success of the process, language acquisition does not end at age 6 or at puberty (the end of the critical period) but continues throughout the rest of one's life. Indeed, adult SLA suggests that speakers can develop idiolects at any age. Native speakers actually modify their idiolects, more evidently when changing their interaction networks and especially when relocating to different dialectal areas.

The emergence of populationwide characteristics makes it more compelling to invoke various ecological pressures to account for why some variants produced by some individuals, but not necessarily the same speakers all of the time, are favored over others. Invocations of population structure (which determines who interacts with whom, where, and on which occasions, and who is more likely to accommodate whom) should also explain why variation is not usually eliminated in the first place. Thus, positing different ecology-specific scales of markedness is more informative than invoking the universal scales proposed by typologists. Ecology-specific scales account more concretely for the features of particular idiolects and other language varieties that emerge in specific interactive settings. The usefulness of the universal rankings may be questioned, given that many populations appear to ignore these rankings in setting the parameters of their language varieties and instead select typological options that some linguists have stipulated as marked. 
The ultimate lesson here is that the emergence of creoles need not be treated as an exceptional phenomenon (e.g., Chaudenson, 1992; DeGraff, 2003; Mufwene, 2001), notwithstanding the fact that every case of evolution in a specific setting has peculiarities that make it unique. A critical assessment will be offered as to what there is in the scholarship on SLA that can provide information about the emergence of creoles as instantiations of language evolution. Attention will be drawn to aspects of the emergence of creoles that may raise issues about some accounts of SLA or that clearly need not be associated with SLA.

It should be remembered that the literature on SLA has typically focused on individual language acquisition experiences with no account of how communal norms arise, whereas that on the emergence of creoles and language evolution has generally focused on changes at the communal-norm level. Although individual speakers are indeed unwitting agents of change (Mufwene, 2001), the role played by the invisible hand in bringing about new norms cannot be ignored, nor can the various ecological factors that affect the relevant population in which the invisible hand operates be disregarded. Véronique (1994) had a sense of the problem that arises from attempts to account for the emergence of creoles with SLA-based hypotheses: according to him, because "creolization is a collective endeavour (...) the social matrices involved are dramatically different" (p. 118). An important difference, which should again be underscored, is that many different agents, who do not all do the same thing or influence the evolution of the TL at the same time, are involved in the emergence of a communal variety. This again demonstrates that even if only SLA were involved in the speciation of the TL into a creole, the evolution from the accomplishments of individual learners to the communal patterns is a complex multiagent process that should not be ignored (see also DeGraff, 2009).

\section{THE EMERGENCE OF CREOLES}

Research on the emergence of creoles over the past two decades has revealed more and more sociohistorical information that accounts for the differential evolution of these new vernaculars (see especially Ansaldo, 2009; Arends, 1989, 1995, 2009; Baker, 1993; Chaudenson, 1992, 2001, 2003; Mufwene, 1996, 2001, 2005a, 2008; Parkvall, 2000a, 2000b; Roberts, 2005; Siegel, 2009; Singler, 1995, 1996, 2009). Much of this research has to do with changing rates of economic development, varying patterns of population growth, variation in colonization styles (such as between Hawai'i and the Caribbean), and changing interaction patterns between Europeans and non-Europeans especially during the 
homestead and plantation phases of the New World and Indian Ocean colonies.

It should have become obvious at this point that pidgins as reduced lingua francas for occasional, minimal communication between parties that speak mutually unintelligible languages could not have served as vernaculars in the homestead colonies from which the plantation colonies evolved. Creolists such as Siegel (2008a, 2009) who cling to the pidgin-to-creole evolutionary scenario beg the question, especially because they suggest that during the homestead phase of the New World and Indian Ocean colonies, the Africans interacted sporadically with the Europeans, contrary to what colonial history has shown. The nonnative varieties of the European vernaculars spoken then by the adult non-Europeans need not be identified as pidgins. The Africans were generally integrated minorities (although discriminated against), and the types of dwellings associated with homestead life were too small and dispersed for them not to interact regularly with the Europeans they lived among. In fact, the Europeans depended on the Africans to survive in the new, tropical ecologies (Wood, 1974). Black and white Creole (or locally born) children grew up together and spoke as their vernaculars the same colonial koinés of the European languages.

The colonization of Hawai'i differed from that of the Atlantic Ocean and Indian Ocean. In any case, although its colonization had no identifiable homestead phase prior to the development of large plantations, the first form of English spoken there was not pidgin. American missionaries, who had arrived early, taught their language to the monarchy and upper class, whose members would act as interpreters both in Hawai' $i$ and in the Pacific. ${ }^{4}$ The members of the different ethnolinguistic groups continued to speak their own vernaculars on the Hawaiian plantations, as these groups were hardly mixed but instead segregated by ethnic houses. They communicated with the plantation owners or overseers through their foremen, who acted as interpreters. Unlike in the Atlantic Ocean and Indian Ocean, a pidgin English emerged out of the occasional cross-ethnic interactions among the contract laborers (not slaves) on the plantations. Unlike in the Atlantic Ocean and Indian Ocean, Hawaiian Creole emerged in the city-not on the plantations (Roberts, 1998, 2005).

Creole vernaculars, which developed gradually and were not necessarily identified as such until the late 18th (rather than in the 17th) century in the New World, evolved simply by basilectalization (i.e., structural divergence from their lexifiers), not by complexification from putative pidgin ancestors. The history of how the plantation colonies evolved supports neither the abrupt development hypothesis nor the claim of break in the transmission of the lexifier even in colonies such as Surinam, where most native speakers of the English lexifier left 15 years after the colony had been founded. The fact is that by the time 
segregation was institutionalized in the Atlantic Ocean and Indian Ocean colonies, Creole populations of African descent continued to speak the European colonial koinés as their vernaculars. It was in fact these populations that served as models for the Bozal slaves imported later.

The reasons for the basilectalization of the lexifier in the plantation settlement colonies are thus similar to those of today's indigenization of the European languages in Africa and Asia, where nonnative speakers have served as models for new learners. Communication among nonnative speakers, especially outside the homeland of the TL, fosters divergence from the original variety of the language brought to the colony (Mufwene, 2009a; Schneider, 2007). Creoles are most likely to have developed when the proportion of seasoned slaves serving as model speakers to the Bozal slaves and to children exceeded that of the Creole slaves (Baker, 1993; Chaudenson, 1992, 2001)—that is, during the 18th century.

The case of Surinam actually also demonstrates that the emergence of creoles need not be associated with one exclusive lexifier. Nor should the slaves be considered the only agents responsible for the divergence of creoles from their lexifiers. The presence of Portuguese on the plantations of the Surinam interior cannot be ignored when accounting for the development of Saramaccan and neither can that of Dutch in coastal Surinam when explaining the development of Sranan. Although most English colonists left Surinam around 1681, quite a few stayed. The Dutch colonists and other Europeans who continued their business in the trade of fur and other commodities in the colony maintained English as the colonial lingua franca. It would be another couple of decades before large plantations developed as the primary industry. These plantations provided the social conditions for the disenfranchising of particular ethnic varieties as creoles. In the meantime, like in many places around the world today, the colonial lingua franca would be spread more by nonnative speakers, including Europeans, than by native speakers. Therefore, the contribution that the Dutch and the other nonEnglish Europeans made to the emergence of Surinamese creoles cannot be discounted. This factor is as important as the fact that the lexifiers of creoles were nonstandard varieties.

The European koinés to which the first slaves were exposed changed gradually as the size of the colonies' populations increased substantially and the communities became racially segregated. Therefore, the model speakers no longer included only the earliest Creole slaves, who had learned the colonial vernaculars natively, but also seasoned slaves, who spoke these vernaculars only as L2 approximations. As in any population and with any language, the TL was structurally different for every new generation of learners (e.g., Chaudenson, 1992), bearing in mind that the concept of generation does not apply literally to human populations. Proponents of the target shift hypothesis (Baker, 1990, 
1996; Becker \& Veenstra, 2003; Kouwenberg, 2006; Mather, 2006) are correct to the extent that they underscore the fact that a proportion of the Bozal slaves who arrived from the early 18th century onward were exposed to something that was identifiable already as creole, by social decree rather than based on any structural features (Mufwene, 2000). However, similar comments can be made about the linguistic experience of European immigrants who came to North America around the same time, as they must have encountered not necessarily the 17thcentury metropolitan English varieties or the early colonial koinés spoken by the earlier settlers but some colonial English varieties that were already American.

However, as pointed out by Chaudenson (e.g., 1992), the emergent creoles did not necessarily displace the closer approximations of the colonial vernaculars spoken by the homestead slaves. Alleyne (1980) had already correctly remarked that creole continua are as old as the history of the slave colonies themselves, although the structural span and the specifics of the continua have varied from one colony to another, just like the specific nature of the local acrolect and basilect in each one of them. Another noteworthy aspect of the changing populations of the colonies should be pointed out: Given the general pattern of population growth during the plantation phase, more by importation of new labor than by birth (Chaudenson, 1992, 2001, 2003; Mufwene, 1996, 2001, 2005a), particular substrate influences could have been enhanced by particular ethnolinguistic groups if more and more of them converged to a particular colony. Such demographic convergence is one of the conditions that offset the founder effect (Mufwene, 1996, 2001) and that can account for Aboh's $(2005,2006,2009)$ question as to why the same Gbe-speaking populations apparently did not exert identical linguistic influences in Haiti and in Surinam. As a matter of fact, Arends (2009) showed that the demographic significance of different African ethnolinguistic groups in the New World varied from one period to another. Perhaps future, better informed comparisons of patterns of population growth in different colonies will show that the same dominant ethnolinguistic groups arrived at different times and faced differing conditions of language contact.

It may be worthwhile at this point to clarify, despite Michaelis's (2008b) claim, that substrate influence does not necessarily determine what the structures of the relevant creoles will look like but rather why and how some creole structures have diverged from those of their lexifiers. Creolists have generally overlooked the fact that creoles probably share more structural properties with their lexifiers than the divergences that have been capitalized on (Aboh, 2009; DeGraff, 2009; Mufwene, 2005a, 2008, 2009b). These include features such as preposition stranding in English creoles, the notion of definite article (not to be confused with the definite determiner) 
and its position within the NP, the position of the adjective, the position and basic structure of the relative clause, the position of the aspectual marker, and the basic order of major constituents in a sentence.

Moreover, focusing on the significance of substrate influence, congruence between features of the lexifier and of some substrate languages may favor (with modification) particular structural options in the relevant lexifiers (e.g., Chaudenson, 1992; Corne, 1999). In some cases, relative homogeneity among the substrate languages may lead the learners to select the emergent variety's options that reflect patterns of these languages (Keesing, 1988; Mufwene, 1986; Singler, 1988). ${ }^{5}$ This indeed appears to have occurred everywhere. Michaelis (2008b) invoked substrate influence to account for the divergence of the features of a creole or expanded pidgin from its lexifier, including the ditransitive constructions in Seychelles Creole. In other cases, as illustrated by Kouwenberg (1994) regarding Berbice Dutch, the privileged position of a particular substrate group can favor the introduction of morphemes and functions from their language(s) into the creole. However, things have not always worked in such clear-cut ways. Even Kouwenberg (2009) now argues that those who introduced Ijo elements (with modification) into Berbice Dutch may not have been the Ijo speakers themselves. In any case, substrate influence is not deterministic.

As is evident from Aboh and Smith (2009), Michaelis (2008a), and Ansaldo et al. (2007), for instance, most creolists today allow for substrate influence on the structures of creoles. Chaudenson (e.g., 1992) correctly observed that the structures of these vernaculars would have been closer to those of other colonial vernaculars, such as Louisianan, Québécois, and St. Barthsian French dialects, had it not been for the influence of African languages. Along with Corne (1999) and Mufwene (e.g., 1996), Chaudenson (1992) argued that most of this influence was in the form of (partial) congruence (what Thomason and Kaufman, 1988, called convergence), with particular options already available in the lexifier favored by similar structural features in (some) substrate languages. In Haitian Creole, such features include the phrase-final position of the determiner (derived from the distal demonstrative, as in nom la "the man"), postnominal use of invariant pronouns in possessive function in Haitian (as in papa mwen "my father"), and the use of free preverbal morphemes to mark tense and aspect. ${ }^{6}$

Aboh (2009) detailed ways in which the grammar of a creole can in some respects be like the lexifier and in others like particular substrate languages but actually different from both. For instance, he showed that the semantics of the determiner system in Saramaccan is closer to that of Gungbe, whereas the morphosyntax is consistent with that of English. The evolution of French into Haitian Creole seems to have favored Gbe influence on the morphosyntax more so than in the 
semantics (Aboh, 2006). Thus, the competition need not have been resolved in terms of win all or lose all. ${ }^{7}$

The congruence was therefore often only partial and entailed generalization or partial modification of an option available in the lexifier, such as the omission of the preposition in papa mwen "my father" (vs. French papa à moi) in some varieties of Haitian Creole. As in the case of Saramaccan, Aboh (2006) also showed that the Gbe patterns were not always faithfully reproduced in Haitian. Thus, for instance, unlike Gungbe, Haitian Creole does not have "weak possessive pronouns" or a "possessive marker of any sort to express possession" (p. 226); instead, it relies only on word order. Such variation in the nature and significance of substrate influence from one creole to another underscores the need for an ecology-specific competition-and-selection approach (Aboh, 2007, 2009; Ansaldo, 2009; Clements, 2009; DeGraff, 2009; Mufwene, 2001, 2002b, 2005a, 2008; Neumann-Holzschuh, 2008) to account for the restructuring with feature-recombination mechanisms that yielded the new linguistic systems. ${ }^{8}$ Thus, the syntacticsemantic properties of the Haitian indefinite determiner are not identical to those of Gungbe. Aside from being prenominal, like its etymon un "one" in French, yon does not combine with a plural counterpart to mark indefinite plural. Gungbe has constructions such as the example in (3).

(3) Súrù kù móto lo le wá

Suru drive car DET PL come ${ }^{9}$

"Suru drove some cars back."

(Aboh, 2006, p. 240)

Like Chaudenson $(2001,2003)$, Siegel (2006) pointed out that no study in naturalistic SLA supports Lefebvre's $(1998,2004) \mathrm{RH}$. Interestingly, in agreement with Lefebvre (1998), Lumsden (1999) remarked that relexification does not seem to apply if the learner has "sufficient exposure to the correct forms [and structures], as produced by native speakers of the target language" (p. 133). It is presumed that relexification occurred in the case of creoles because the slaves did not have sufficient exposure to the lexifier, a position not entirely consistent with the socioeconomic history of the colonies. It must be remembered that segregation of the slaves from the European populations did not mean the end of sufficient access to their language, because there were Creole slaves who spoke the European colonial koinés natively. There were subsequently seasoned slaves who had learned some approximations of the early Creoles' koinés. The rest is a story of gradual divergence from the lexifier as spoken earlier on the homesteads rather than absence of sufficient exposure to the TL.

It is noteworthy that Perdue (1995) provided evidence that the deviant interlinguistic utterances produced by Spanish speakers learning 
French, such as the omission of the copula in equative and attributive sentences and misuse of the complementizer que in relative clauses, do not necessarily reflect L1 influence. Furthermore, the problems that these Spanish learners have with the conjugation of French verbs could not be caused by interference from their L1, especially when inflections are confused or overgeneralized or when resumptive pronouns are used in relative clauses. Likewise, although it is true that some of the deviant utterances attested in the French interlanguages of Moroccan immigrants are due to the influence of Arabic, there are also many nontargetlike utterances, including some similar to those produced by Spanish immigrants, that cannot be attributed to Arabic influence. Perdue's conclusion was that, although similarities between mother tongue and the TL facilitate SLA, differences merely slow the process down but do not necessarily predetermine the particular interlinguistic structures produced by the L2 learners. Thus, Pienemann (2003) was correct in underscoring the gradual capacity of the learner to process L2 structures adequately as a factor that determines the progression and outcome of SLA. Misanalyses of L2 structures contribute to the divergence of the learner's idiolect and perhaps to that of the emergent communal variety but need not be associated with substrate influence.

In any case, although in support of substrate influence, Aboh's (e.g., 2006) meticulous comparisons of Gungbe structures with those of Haitian Creole, Saramaccan, and Sranan show that there is generally no literal mapping of French or English words onto those of Gbe languages. The situation was much more complex and the differences too many to attribute the divergence of the structures of creoles from those of their lexifiers simply to relexification (DeGraff, 2009). This finding is consistent with Helms-Park's (2003) analysis of causative serial-like constructions produced by some Vietnamese learners of English-interestingly, only by one third of the participants. Moreover, deviations occurred even in structures for which there is congruence between Vietnamese and English grammars.

There is also plenty of evidence to support the position (misidentified by some as the superstrate hypothesis) that many, if not most, of the structural features of creoles are a legacy of their lexifiers, such as the fact that Caribbean English creoles typically have stranded rather than pied-piped prepositions in relative clauses and in questions as well as prenominal determiners and adjectives (Mufwene, 2001, 2008). Even constructions such as dis-ya bway or dis bway ya "this boy" have their origins in nonstandard English (the demonstrative this-here is attested in some varieties), as do double modals. Aboh's $(2006,2009)$ arguments for the hybridity of creole structures are a more explicit articulation of the complementary hypothesis (Baker, 1993; Hancock, 1993; Mufwene, 1986, 1993a), which has been elaborated into an ecological approach since Mufwene (1996). Similarly, DeGraff $(1999,2009)$ shed light on the 
differing ways that both children and adults contribute to the emergence of creoles, with children functioning as important agents of selection at the communal level. He also raised the question of whether competition arises only from the options already available in the languages in contact. Competition actually arises from all the elements produced by speakers and learners, including innovations, provided they become part of the communal feature pool. The focus now shifts to the question of what to expect from cross-pollination between research on SLA and scholarship on the development of creoles.

\section{HOW RESEARCH IN SLA AND ON THE EMERGENCE OF CREOLES CAN CROSS-POLLINATE}

Most of the research on SLA has been based on classroom experience. It is probably worth emphasizing here that it is comparisons with phenomena observed in naturalistic SLA, such as the interlanguages of migrant workers, that are more likely to shed light on the emergence of creoles. However, the difference in focus between individual learning experience and communal language evolution should be noted. Creoles are ultimate outcomes of naturalistic language learning, through attempts to communicate in the language of the economically dominant group, with the difference that creoles have developed their own separate norms. There have been no opportunities for students of SLA to study the emergence of communal norms.

This caveat should cast doubt on studies such as those of Mather (2006) and Plag $(2008,2009)$ that reduce creoles to fossilized or earlystage interlanguages. Siegel (2009) aptly remarked that most interlanguage features are more similar to those of incipient pidgins than those of creoles. Until convincing evidence of the (general) evolution of creoles from pidgins is adduced, it appears that comparisons of creoles with interlanguages are informative insofar as they make us (more) aware of the various ways in which transfer occurs and how gradually new systems, transitional or stable, emerge. Citing Hansen Edwards and Zampini (2008), Plag (2009) claimed that "it is within the domain of L2 phonology (...) that transfer is the most prevalent" (p. 122). It is ironic to note that prosodic features, the starting point of Plag's discussion, represent one area in which creoles have generally failed to confirm substrate influence. The vast majority of creoles are not tonal language varieties (McWhorter, 1998), unlike the African substrates of Atlantic Ocean and Indian Ocean creoles.

Segmental phonemes are a mixed bag. Creoles vary significantly from one another and even internally in their respective systems, as can be illustrated with English creoles. Whereas Surinamese creoles represent the extreme case of the reduction of the segmental inventory, Gullah 
represents just the opposite. For instance, Gullah has preserved the schwa (generally missing in Caribbean creoles), has a bilabial fricative (rare in African languages, this has apparently been retained from the English of Irish indentured servants but realized as [b] in the Caribbean, as in [beks] "angry" from vexed), uses the modern English pronunciation of the vowel of cup and country (with $[\Lambda]$ ), and has diphthongs similar to those of North American English. At the same time, the labiovelar and prenasalized stops that appear in some African names (Turner, 1949) have been modified as velar plus bilabial stop and nasal plus oral stop sequences, respectively (Mufwene, 1985). In the case of Jamaican Creole, the palatalized pronunciation of the first syllable of words such as garden and car and the absence of rhoticity in the same words is a legacy from 17th- and 18th-century metropolitan English (Patrick, 1999). The same is true of Jamaican pronunciations such as /gwot/ "goat" and /gwayn/ "going," which were commonly used among European colonists. Some of these features are also attested in Irish English (Odlin, 2003). Therefore, although there is evidence of variable substrate phonological influence in English creoles, it could also be argued that these vernaculars are useful windows into some of the features of the English koinés spoken in the colonies in the 17th and 18th centuries. ${ }^{10}$

It should certainly be kept in mind that creoles are population-level phenomena and the study of their emergence has not had the benefit of observing phenomena at the individual learner's level. ${ }^{11}$ However, there are no studies of group SLA that involve learners interacting with each other in the target language. Studies such as those of Perdue (1995), Klein and Perdue (1992), and Giacomi, Stoffel, and Véronique (2000) only report features that are statistically common in the speech of individual learners; these studies are not accounts of communal norms that result from the convergence of individual speakers' communicative strategies. As pointed out by Perdue and by Helms-Park (2003), for instance, there is a lot of interindividual variation in the interlanguages of learners (see also Ellis, 2004), aside from the obvious fact that there are no studies of the ultimate outcome of the learning process, which would be the most suitable for comparison with creoles. This observation is also confirmed by Gabriele and Martohardjono (2005), who noted:

Group results are often misleading in cases where the group mean is low because it may be the case that half of the learners performed at very high levels of accuracy while the other half performed at very low levels of accuracy. (p. 103)

Caution should thus be used when noting parallelisms between foreign workers' linguistic characteristics and creoles' peculiarities, because individual speakers' properties do not necessarily translate 
into population-level characteristics, which is what norms are. Although the study of foreign workers' interlanguages clearly shows that substrate influence plays a role in (naturalistic) SLA, it also shows that substrate influence does not occur consistently from one learner to another (Perdue, 1995) and is not an ineluctable phenomenon in all aspects of SLA.

It is also worth underscoring in this case that although foreign workers live in ethnically segregated neighborhoods in which they usually socialize among themselves, they typically communicate with one another in their heritage language rather than in the host country's vernacular. Unlike the populations that developed creoles, foreign workers use their approximations of the host country's language primarily, if not exclusively, to communicate with the host population-that is, the majority in which they are hardly integrated. In other words, the host country's language functions as a lingua franca, not as a vernacular, for the adult immigrants. The story is different for their children, who usually learn the local vernacular more successfully through their more regular interactions at school with native children; children of immigrants are more likely to influence their parents than to be influenced by them. Prepubescent immigrant children are able to develop native competence in the host vernacular.

It is undoubtedly tempting to consider these children as a test case for DeGraff's $(1999,2009)$ and Mufwene's (2004, 2008) hypothesis that children are important agents of selection who determine which particular substrate features will be passed on to the next generation of learners of the colonial vernacular. This may very well be the case, although conflicting patterns of assimilation and segregation prompt the immigrants' children to become fluent in the host language, whereas the parents make little progress. However, because the parents do not communicate among themselves in the host language, no particular, normalized, communal nonnative variety of this language emerges. Siegel's (2009) observation that the emergence of foreign workers' interlanguages is the most comparable to the development of incipient pidgins, involving especially adult speakers, is thus questionable. Pidgins have emerged largely from interactions that nonnative speakers of the TL had with each other.

Perhaps the best support for Siegel's (2009) observation may come from Hawai'i, where a pidgin emerged on the plantations because the contract workers were segregated by ethnolinguistic backgrounds and needed English to communicate across these boundaries. Otherwise, none of the foreign worker groups' interlanguages that have been investigated to date has evolved to function as the vernacular of any of the relevant immigrant populations. As noted, the group characteristics of the interlanguages that linguists have discussed as typical of migrant workers' speech (e.g., Spaniards or Moroccans learning French) are 
simply generalizations that are better interpreted as mere statistical patterns rather than as established norms that have arisen from the accommodations that individual speakers make during their interactions with one another.

An important difference between these situations and the trade settings in which pidgins have evolved is that, in trade settings, the indigenous children continue to acquire their heritage languages as their vernaculars, whereas the immigrant children tend to give up their heritage languages. Children in settings where pidgins emerged were thus more likely to be influenced both by their heritage languages and their parents' productions of the new lingua franca. The children hardly had any exposure to the native or full-fledged varieties of the European languages that their parents had been exposed to, albeit sporadically. Once the children started using the new lingua franca to communicate among themselves, they could also contribute their own share of restructuring during its expansion into a vernacular (the case of expanded pidgins), as illustrated by Jourdan's (2009) study of the derivation of transitive verbs from prepositions in Solomon Island Pidgin, as in (4).

\section{(4) Mami bae insaetim kaleto Mother FUTURE take-inside laundry \\ "Mother will take the laundry inside."}

In this example, the word order is English (contrary to the verb-subjectobject structure of the substrate languages), but the derivation pattern is largely Melanesian, although the etyma of both the predicated preposition insaet and the suffix -im are from English.

These caveats aside, other aspects of SLA that bear on the emergence of creoles, including whether it is justified to invoke competition and selection as part of the process, can now be investigated. A convenient starting point is nonnative accent, which at the population level is easily confirmed in settings that are exogenous to the TL but endogenous to the colonized population. Evidence for such a nonnative accent is found in indigenized Englishes of Africa and Asia and in African varieties of French, which function as lingua francas among their nonnative speakers. It is also noteworthy that these varieties have evolved from the scholastic varieties that the Europeans introduced in their exploitation colonies to train their indigenous civil servants, who functioned as colonial auxiliaries. ${ }^{12}$

What is best illustrated by these evolutions is that even formal training does not necessarily rid the emergent varieties of influence from their indigenous vernaculars. Additionally, situations in which nonnative speakers serve as linguistic models to L2 learners lead to increasing divergence from the original native model (Bambgose, 1992, 1998; Kachru, 1996, 2005). This is the kind of evidence that makes it 
plausible to accept substrate influence as an explanation for some of the ways in which creoles diverge from their lexifiers, except that, as now made more obvious by Aboh (e.g., 2006), the specificities of that influence must still be shown. Recall that substrate influence is only one of the possible explanations; it is not absolute but instead applies selectively.

In relation to the cafeteria principle (which attributes the origins of the new system's features to diverse languages, almost by chance; Dillard, 1970), which has often been used to question the possibility of substrate influence, it is quite interesting that one can see some sort of national or regional accent emerge even in highly multilingual places such as Nigeria and India for English, or Senegal and the Democratic Republic of Congo for French. Selection seems to have operated convergently among different idiolects in every territory, although the role of the founder principle (which tends to favor features of the founder population over those of the latecomers; Mufwene, 1996, 2001) must be factored in, invoking, for instance, whether French was introduced by the French or by Belgians. This factor bears on the distinction between, on the one hand, the indigenized French varieties spoken in former French colonies and, on the other hand, those spoken in former Belgian colonies (Democratic Republic of Congo, Rwanda, and Burundi). At the macrolevel within each setting, where some subtle differences can be overlooked, selection seems to have leveled out traits that may be associated with particular languages (Kachru \& Nelson, 2006). Selection has produced some sort of pan-ethnolinguistic, national variety, especially in urban centers, although the locals can generally tell the particular part of the country that a speaker is from (an exercise that is difficult for outsiders).

Thus, the debate over the significance of substrate influence on creoles should have been not whether there was substrate influence but how much and of what specific kinds as well as which particular factors favored the influence. This question is closely related to that of how local norms emerge that would make some ways of speaking the colonial language more normal and typical of particular groups than others. Given the focus of SLA research on individual learning rather than on the emergence of particular nonnative norms, these are questions that genetic creolistics and research on indigenized varieties will have to address. Because some of the processes are still underway or quite recent in the indigenized Englishes and African French, some insights may come from studying these varieties.

Perdue's (1995) investigation of naturalistic SLA brings up interindividual variation among his participants, even among those from the same ethnolinguistic background. Although motivation for becoming fluent in the host country's language and assimilating to its culture has been invoked as a factor (see, e.g., Dörnyei \& Skehan, 2003; Ellis, 2004), it is not nearly as significant as interindividual variation in L2-learning 
skills and in the frequency of interactions the immigrants have had with the host population. Even the lack of motivation invoked by Schumann (1978) and often cited in subsequent publications is ultimately attributable to these factors. The alleged lack of motivation is correlated with the people an immigrant socializes with and the employment he or she finds. An underlying factor shared by all immigrants is thus how they can adapt to the host country. Adaptation entails learning the host country's language and is subject to the dynamics of the local population structure, which has been well explained by, for instance, Douzet (2004) and Lopez and Estrada (2004) in the case of Hispanic immigrants to the United States. Barkhuizen (2004) discussed this factor in relation to social influence on language learning. ${ }^{13}$

Much of this variation is reminiscent of what is found in the so-called creole continua, although, as pointed out by Chaudenson (e.g., 1979), these continua largely reflect variation in the learners' foreign language skills, in the particular speakers from whom a slave has learned the local colonial vernacular, and in the age at which the TL was learned. Like other naturalistic L2 learners, the individual Bozal slaves that spoke the same languages most likely did not transfer the same substrate features into their emergent idiolects. The scenario is further complicated by the fact that the ethnolinguistic backgrounds of the slaves varied, despite many shared areal features (Gilman, 1986).

From the perspective of language evolution, the domain of the invisible hand is thus implicated; through what has been identified as competition and selection, this produces the new norm. The norm does not necessarily eliminate variation but simply defines the range of variation that characterizes particular speech as indigenous or nonindigenous to the group. Although studies of naturalistic SLA heighten awareness of the question of the emergence of communal norms, they do not provide any better explanation, as compared with creolistics, of how normalization occurs. Kouwenberg (2008) was mistaken in assuming that normalization would have produced a homogeneous creole in Jamaica, and more dubiously, as early as the late 17th century. According to Dunn (1972), in the late 17th century, Jamaica was unevenly settled and homesteads were the norm, compared to the handful of plantations (which were not as large as those of the 18th century) that had developed. ${ }^{14}$

The slaves did not all develop identical idiolects. Although some slaves did indeed reach comparable levels of competence in the local colonial vernacular, many probably did not. Furthermore, the expectation for comparable levels of competence should be relative to specific acrolectto-basilect continua, which have varied from one colony to another even relative to the same lexifier. The mutual accommodations that ensued from their interactions with each other, about which naturalistic SLA reveals nothing, must have played an important role in the emergence of plantation- or colony-specific norms, which defined the respective 
ranges of normal variation. ${ }^{15}$ These interindividual accommodationsone of the ways selection works within a population (e.g., Mufwene, 2001) - appear to be different from the mechanism of dialect-leveling invoked by Lefebvre $(1998,2004)$.

Unlike in Hawai'i, where contract laborers lived in separate ethnolinguistic houses and actually needed a pidgin to communicate across ethnic groups (Mufwene, 2004, 2008; Roberts, 2005), slaves in Caribbean settlement colonies were typically ethnically mixed and did not have opportunities to develop ethnic varieties of the colonial vernaculars any more so than urban educated Africans have been able to develop ethnic varieties of the colonial lingua francas. ${ }^{16}$ If the competition-andselection process, which is gradual, were to be equated with Lefebvre's $(1998,2004)$ leveling process, this would be tantamount to denying the RH, which, surprisingly, Sprouse (2006) and Schwartz (2006) claimed to be the initial state for every L2 learner. Competition and selection apply at all stages of the language acquisition process and, as if this was not complex enough, cross-individually at all stages of the autonomization and normalization of the colonial vernacular into the variety disfranchised as creole.

Assuming relexification, the basic difference between the SLA and the creole development scenario would presumably lie in the supposition that the African slaves would have maintained the same initial state throughout the SLA process and that the children of the adult slaves would have been exposed only to these relexified varieties and would have contributed nothing to the creole emergence process, except apparently to the putative dialect-leveling process. Singler's $(1995,1996)$ account of the history of the development of French Antillean colonies, on which Lefebvre's $(1998,2004) \mathrm{RH}$ has relied, does not support this evolutionary scenario. Could Sprouse's (2006) and Schwartz's (2006) position be interpreted to mean that the learner can capitalize on knowledge of the L1 whenever similarities are perceived between the L1 and the TL? This can account for some of the errors, especially in the direction of overgeneralization or rule restriction, which occur in the learner's interlanguage and can fossilize even after he or she has developed acceptable communicative competence in the TL. Recall, however, that not all deviations in SLA are attributable to L1 influence.

The null hypothesis must be that the learner expects the TL to be different from his or her L1 and every effort must be made to speak the TL in the best way he or she can. Thus, nonnative speech occurs in spite of the learner's intention to produce speech that falls within the normal range of variation found among native speakers. Similarly, creoles have emerged despite the slaves' intention to speak the local colonial vernacular in the same way as those who preceded them, in contrast with Baker's (1997) conclusion that hypotheses of imperfect SLA suggests that the slaves failed in their endeavor to appropriate 
the European language. Such a negative conclusion is disputed by an underlying premise of the present essay-namely, that all language acquisition processes are imperfect, even within native-speaking populations. The very assumption that L1 acquisition is perfect would be antithetical to admitting the reality of idiolects; no single idiolect replicates another in a population of speakers, even among natives. Wolfram (2000) demonstrated this position clearly.

Returning to the case of Haitian Creole, it is assumed, as in Lefebvre $(1998,2004,2008)$, that by the time of Haitian independence in 1804, the bulk of the vernacular spoken by the overwhelming majority of the slaves was already formed. During the Haitian revolution that led to this event, the French colonists either escaped or were killed, and no more slaves or contract laborers were imported afterward (Baker's, 1993, Event 3$).{ }^{17}$ In fact, the plantation industry would soon collapse, as the former slaves did not want to work on the plantations any more. The prerevolution economic system largely shifted to small subsistence farming (Barthélemy, 2000).

It is also assumed that the regional and social variation richly documented by Fattier (2000) partly reflects the long-lasting memories of linguistic populations (Kretzschmar \& Tamasi, 2003). The leveling of presumably ethnic dialects invoked by Lefebvre $(1998,2004)$ most likely did not apply. Although Bickerton (1981) reported that early Hawaiian Pidgin English varied according to the ethnolinguistic backgrounds of speakers, slave populations in the New World were more ethnically mixed than the contract laborers of Hawai'i. Additionally, postrevolution population movements in Haiti probably did not affect the traditional regional dialect boundaries any more than the postcolonial population movements in the United States. Wolfram (2008) reported that these boundaries have not changed since the colonial period, although specific dialect features may have changed.

Although there may be plausible evidence for the $\mathrm{RH}$ at the individual speaker's level, where it has been correctly situated by Lefebvre (1998, 2004, 2008) and Lumsden (1999), no convincing explanation has been provided for the extrapolation of this process to the population level. However, recent detailed comparisons of structural similarities between, on the one hand, Gungbe (similar to Fongbe) and, on the other, Haitian and Surinamese creoles by Aboh (e.g., 2006) point to the emergence of hybrid systems influenced by both the lexifier and the substrate languages, which is consistent with several analyses provided by DeGraff (e.g., 1993).

These observations are entirely consistent with Corne's (1999) hypothesis on the role of congruence between substrate and superstrate features in the emergence of French creoles and certainly consistent with the complementary hypothesis, which has been more adequately articulated from an ecological perspective since the publication of Mufwene 
(1996). ${ }^{18}$ Studies of naturalistic SLA and the development of creoles are, of course, confronted with the question of what principles account for the seemingly selective ways in which some aspects of the TL or lexifier have been learned faithfully, some substrate features have found their way into the emergent varieties, and some other peculiarities have also emerged that are not (entirely) consistent with either the lexifier or any of the relevant substrates. The evidence clearly shows that it is not the cafeteria principle that is ill-conceived but rather an account of this principle that is still lacking (Mufwene, 1996, 2001, 2005a; Siegel, 2008b).

The literature on naturalistic SLA provides information that supports Mufwene's (e.g., 1996) ecological approach. Success differences between adult and child learners in the acquisition of the TL are correlated not only with the fact that children's minds are more plastic than those of adults but also largely with the fact that children interact more regularly with native-speaking children and among themselves under conditions that foster more progress toward closer approximations of the TL, which includes the normal range of variation. School-age immigrant children are probably less often spoken to in foreigner talk than the adults are. The same literature also highlights the role of other ecological factors, such as level of education, prior exposure to the TL, time spent in the host country, and the nature of interactions with members of the host population.

However, information about variation in L2-learning skills remains implicit; and the literature says little about the varieties to which the immigrants have been exposed. For instance, children are more likely to have been taught the standard variety at school, although they learn much of the vernacular varieties through their interactions with nativespeaking children from both the host and the immigrant populations. Although suburban French vernaculars have emerged that are associated especially with children of immigrants, these varieties are clearly different from the L2 approximations produced by their parents and are far from being so-called broken speech. Some of these, such as Verlan, the suburban teenage French variety marked particularly by the permutation of syllables in polysyllabic words, may be treated as counterlanguages. True to their definition, these suburban varieties have evolved from manipulations of vernaculars that had arisen naturally and that were closer to those spoken by the adult native populations.

Given that SLA normally evolves toward the development of some acceptable competence in the TL-aside from the experience of migrant workers-it is tempting to invoke fossilization, extrapolated to the population level, to account for the emergence of creoles. This is precisely what Lefebvre, White, and Jourdan (2006a) did in attributing creolization to "insufficient access to the superstrate language" (p. 10). First, as pointed out by Ellis (1994), there are diverse reasons for fossilization. 
Some of them may be internal to the TL itself-for instance, variation in the usage of the definite article in constructions such as going to (the) college and watching (the) TV. Just like Mather's (2006) and Plag's (2008, 2009) invocations of interlanguage, Lefebvre et al.'s (2006a) interpretation of fossilization as "incomplete' acquisition" (p. 9) is also reminiscent of associations of the emergence of creoles with imperfect language learning. Every language acquisition process is incomplete and imperfect; the idiolects of the model population vary infinitely and learning does not end until a speaker or learner becomes incapacitated or dies.

As for insufficient access to the lexifier, its invocation to account for the emergence of creoles is a myth that has associated full command of the European colonial koiné targeted by the earliest slaves of the posthomestead phase exclusively with the European colonial population. The socioeconomic histories of the territories where creoles have evolved suggest that by the time the colonial populations were racially segregated at the onset of the plantation phase, there were many Creoles of non-European or mixed descent who were native speakers of the same colonial vernaculars as the Creoles of European descent; these non-European Creoles served as model speakers to the Bozal slaves arriving fresh from Africa. Eventually, some model speakers were seasoned slaves, who spoke L2 approximations of the local colonial vernacular. However, there was no time when the slaves had insufficient access to the lexifier. Assuming Baker's (1993) periodization, the emergence of varieties identified as creoles took place between Event 2, when the foreign-born slaves outnumbered the locally born, and Event 3 , when slave importation ended. Thus, many Bozal slaves were exposed not (primarily) to the original lexifier but to some modified L2 variety already influenced by xenolectal influence. ${ }^{19}$

If fossilization is interpreted as the persistence of deviations from the norm even after the learner's competence has evolved closer to that of the model population, then creoles would have to be conceived of as outcomes of group language acquisition processes marked by anomalous amounts of persistent deviations from the TL. However, although creoles are divergent from their nonstandard European lexifiers, such divergence is certainly not limited to creoles nor are the restructuring processes that produced this divergence unique to them (DeGraff, e.g., 2003; Mufwene, 2001, 2005a, 2008). As conservative as creoles and other colonial vernaculars of the same European languages are in retaining features that may have disappeared in the metropolitan varieties, it does not seem accurate to treat these creoles and the other vernaculars as fossilized varieties.

The other arguments presented here especially question Plag's $(2008,2009)$ invocation of interlanguage as an explanation for how creoles emerged. The position sounds as if creoles reflected SLA in an arrested stage, with the learners having no opportunity to develop closer 
approximations of the TL. It is as if the plantations had been populated and had developed overnight, all the slaves targeted the same vernacular (i.e., there was presumably no variation among the model speakers), and all of the learners had identical SLA skills. And then, consistent with the pidgin-to-creole evolutionary scenario, segregation from the European colonists would have completely prevented the slaves from accessing the TL. Voilà! The slaves thus had nothing more but their interlanguages to use, unlike, perhaps, some of those indentured servants who were learning the dominant language alongside them. Unfortunately, this language-evolution scenario is not consistent with the gradual socioeconomic developments of the relevant colonies (Arends, 2009; Chaudenson, 2001, 2003; Mufwene, 2008; Singler, 2009).

\section{CONCLUSIONS}

Research on SLA and that on the development of creoles can undoubtedly complement one another-for example, by highlighting what practitioners in one area should not expect to learn from the other in the absence of informative data. Both research areas also present mixed bags of accounts-some more plausible than others. Thus, it is important to be critical of the literature and to carefully assess what is really comparable.

One of the greatest dangers in comparing research on SLA and that on the emergence of creoles lies in extrapolating from findings about individual learners in SLA to population-level hypotheses about creoles. Although research on SLA confirms that it is normal to hypothesize substrate influence on the structures of creoles, it does not show that all learners from the same L1 background transfer exactly the same features into their approximations of the TL, although, to be sure, there are cross-learner similarities on the family resemblance model..$^{20}$ The mechanisms that selectively translate individual-level phenomena to population-level behavior, perhaps subsumable under the invisible hand that drives change (Keller, 1994; Mufwene, 2002a, 2008), still remain to be articulated, although allowance must be made for internal variation from the perspective of the emergence of community norms. Research on SLA cannot inform genetic creolistics in this particular area because it has not focused on the subject matter.

As much as markedness principles have been invoked to explain why particular typological options have become dominant in some vernaculars, the actual mechanisms that account for the spread of some individual speakers' selections to whole populations or to subsets thereof remain mysterious. It is not enough to say that speakers copy selectively from each other; it must be explained why, in the relevant settings, those particular variants (but not others) are copied. It appears 
that communal norms emerge because learning never ends, unless a speaker dies or his or her language faculty becomes incapacitated. From an emergentist perspective, this creates a very complex situation in which norms as a populationwide equilibrium of communicative habits is a construct of convenience (Mufwene, 2009b). In the case of the emergence of creoles, it is important to factor in the generational dynamics well articulated by DeGraff (2009) with regard to the complementary role of adult Bozal slaves and that of children as agents of selection who contributed significantly to defining the PLD to which future learners were exposed.

Note also that although some generalizations have been made about the structures that L2 learners from particular ethnolinguistic backgrounds tend to produce in their interlanguages, no communal interlanguages have been reported; there have apparently been none to study. Migrant workers-the usual focus of research on naturalistic SLA-use their individual interlanguages to communicate with members of the host population or migrants from different backgrounds but not among themselves, especially when they live in ethnically segregated communities in which it is more natural and more efficient to communicate in their heritage language.

Genetic creolists as students of language speciation must singlehandedly face the question of how the emergence of new communal vernaculars proceeds. They may draw inspiration from other disciplines, including unexpected ones such as virology and epidemiology, where such questions about the spread of viruses have been addressed from the perspective of social interactions. These research areas underscore the significance of population structure, which, among other things, determines who interacts with whom and who controls access to whom in the spread of viruses. Population structure plays an important role in the spread of particular linguistic features and in the normalization process.

More recent research on the emergence of creoles, notably by Aboh (e.g., 2006), has shed light on the hitherto unexpected ways in which linguistic features can hybridize as they recombine in various lexical items and in the ensuing linguistic structures in which they are used. This perspective raises important questions about the units of selection used in the restructuring process. The same question of units of selection surely arises about SLA as about the emergence of creoles. It seems that the same fundamental question of competition and selection, which has been addressed with respect to the emergence of creoles at the population level, can also be addressed at the individual learner's level regarding naturalistic SLA. However, note that competition and selection at the communal level presuppose competition and selection at the individual learner's level. In other words, competition and selection at the communal level are ultimately the (partial) 
convergence of individual learning processes through mutual accommodations. The invisible hand is invoked because every learner focuses on communicating successfully-that is, on their individual communicative benefits in interactions that are usually dyadic or triadic; no learner targets the norms that arise from these separate interactions.

Research on (naturalistic) SLA appears also to shed no light on the question of whether creoles evolved from antecedent pidgins as communal varieties. The default assumption about SLA is that the learner's interlanguage is a progression toward a closer approximation of the competence of a fluent native speaker of the TL. In contrast, creoles and pidgins appear to have evolved by divergence away from their lexifiers (Mufwene, 2005a, 2008). A central research question has been how the divergence has proceeded. The phenomena that have interested genetic creolists and scholars of SLA have thus evolved in opposite directions.

Much recent scholarship on the emergence of creoles has also been grounded on the specific socioeconomic ecologies that bear on this speciation process, including patterns of population growth and timing of race segregation. Nothing that approximates this scenario, especially regarding population interactional patterns and dynamics, has been done on SLA. Therefore, care should be taken in determining which aspects of one particular research area can inform the other. In the case of the emergence of creoles, the divergence occurred despite the fact that new learners generally progressed beyond the interlanguage stage and developed acceptable competence in the current TL, which, of course, varied from one period to another and certainly also from one place to another. Things are even more complicated by DeGraff's (1999, 2009) other, more evident realization that both adult SLA and child L1 acquisition contributed innovations and selection of features during the gradual normalization of creoles as communal vernaculars.

None of what has been discussed, in this article as in most of the relevant literature, will make sense without invoking periodization (as different features are likely to have been introduced and normalized at different times) and patterns of population growth in the case of the emergence of creoles. These two factors determine whether the composition and structure of a population remain constant or vary over time and, the founder principle notwithstanding, which particular ethnolinguistic groups arrived and appear to have modified the feature pool at what particular time. These considerations make the gradual restructuring of the lexifier into a creole nonrectilinear and nonunilinear, and certainly variable from one (part of a) colony to another. The contributions that the scholarship on SLA can actually make to understanding the emergence of creoles are thus limited.

It is also important to be more critical of general invocations of universals of SLA to account for the divergence of creoles from their 
lexifiers and to ask which specific universals of SLA researchers have in mind. Do these universals boil down to transfer or imperfect learning? Do they also include simplification or overgeneralization relative to target structures? Mather (2006) suggested that this is indeed the case, invoking morphological simplification or leveling as examples of such universals. However, both simplification and overgeneralization occur in L1 acquisition as well. Additionally, when a person gradually develops competence in either the L1 or the L2, he or she can generate novel features induced by the interactions of what has already been learned. However, Plag $(2008,2009)$ illustrated his universals of SLA with limited processability, which does not seem to be unique to SLA. He provided a longer list that also includes "avoidance, conflation (i.e., neutralization) of categories, or universal developmental tendencies" (Plag, 2009, p. 121), none of which appears to be unique to SLA. It is clear that researchers who invoke universals of SLA to shed light on the emergence of creole structures have not yet articulated what those SLA-specific processes are, other than transfer.

Contrary to Mufwene (1990), transfer or interference at the individual learner's level does not entail substrate influence at the communal level, because competition and selection at different stages of the relevant population growth and of the normalization process may weed out some features. I have argued since Mufwene (2000) that creolization is a social act whereby a particular variety was disowned by speakers of genetically related varieties-not a specific, global language-restructuring process. However, if creolization was in fact the result of language restructuring, how would research on such a population-level process be informed by research on acquisition as an individual learning process, especially given the variation inherent in the emergence of creoles?

Furthermore, what counts as creole-the basilect or the whole continuum from the basilect to the upper mesolect? Because there are linguists such as Chaudenson (e.g., 2001) who speak of acrolectal creole varieties, can creole also be interpreted to apply to the whole continuum, from the basilect to the acrolect, in places where both poles of the continuum evolved and diverged from the nonstandard and standard varieties of the same language? Can inspiration be drawn from a creolization process that is ill-defined? There are quite a few questions that recent publications on the connection between research on SLA and that on the emergence of creoles have not addressed. However, due to space limitations, these questions should also be omitted here.

A particularly informative approach from the literature on SLA (e.g., Gabriele \& Martohardjono, 2005) is the endeavor to identify the particular structural conditions under which specific transfers occur and the particular aspects of features or parametric options involved. This 
especially supports Aboh's (e.g., 2006) particular approach to hybridity as feature recombination, which raises the question of what the units of selection actually are.

Finally, comparisons between SLA and the emergence of creoles have probably focused too much on negative transfer, paying much less attention to positive transfer-that is, the role that the L1 or any language previously learned by a speaker or signer plays in facilitating his or her learning of the TL. ${ }^{21}$ After all, transfer is made possible by perceived similarities between the structures of what is already known and the interpretation of what is to be learned. Transfer need not amount to interference. In fact, transfer can help explain the wellaccepted position in genetic creolistics that the degree of divergence of a creole from its lexifier is inversely correlated with the degree of structural kinship between the lexifier and the substrate languages. It also sheds light on those cases in which the learners selected from among the options available in the lexifier those that were more closely related to some of the substrate languages (by congruence). Although Håkansson, Pienemann, and Sayehli (2002) and Helms-Park (2003) were correct in remarking that interlanguages often include deviant structures even when there is congruence between the L1 and the L2, the evidence from creoles suggests that congruent structures are eventually favored. The relevance of both negative and positive transfer underscores the fact that the emergence of creoles and pidgins cannot be accounted for by simply invoking phenomena associated with SLA, especially interlanguage.

(Received 7 October 2009)

NOTES

1. Since Mufwene (2001), I have questioned the accuracy of the terms language acquisition and transmission. These terms cannot be interpreted literally, especially not like the term transmission in evolutionary biology. It is for want of better terminology that these terms are used in the present article.

2. From an emergentist perspective, which assumes that speakers' competences are in constant search for equilibria and that there may be no static communal grammar targeted by all, the term system is as problematic as the terms acquisition and transmission if system is interpreted as a well-integrated body of units and rules (Mufwene, 2008, 2009b).

3. The basic justification provided by Labov (1998) is consistent with what was proposed by Mufwene's (1992b) argument that grammars are not monolithic systems with rules that complement each other in the way imagined by Meillet (1906) and Saussure (1916). Instead, grammars allow for rules that compete for the same functions but overlap in what the rules do. Individual speakers tend to privilege one competing variant over another, except in domains that present no choice, such as using the possessive relative pronoun in English relative clauses as opposed to functions that allow the clauses to start with either a relative pronoun or a complementizer. It is only Labov's idea of coexistent incomplete grammars associated with different dialects that seems questionable. 
4. Even pidgins appear to have evolved in ways similar to creoles: by gradual divergence from their lexifiers. Interpreters, usually referred to as linguists (i.e., polyglots), were used everywhere in the early stages of colonization (Fayer, 2003; Mufwene, 2005a, 2008). Drastic divergence started when there were fewer and fewer fluent speakers that could serve as interpreters and when more and more speakers who were less fluent in the original variety used the TL as a lingua franca (in the case of pidgins) or as their vernacular (in the case of creoles).

5. Gilman (1986) highlighted the role that areal features (spread over vast linguistic areas in sub-Saharan Africa) must have played in the process of creole emergence. He discouraged scholars from focusing exclusively on features of particular languages or of a particular language family.

6. Congruence appears in fact to be the most significant of the positive constraints on substrate influence discussed by Siegel (2008a). His shifter principle is analogous to Mufwene's $(1996,2001)$ founder principle, except that Siegel appears to assume that the approximations of the first populations that shifted to the lexifier must have been as divergent as those of the latecomers and must have determined most of the substrate influence. Assuming gradual evolution, the features that distinguish creoles from their lexifiers need not have emerged concurrently (Baker, 1995), although some features may be consequences of others.

7. Competition refers to the fact that the variant forms and structures are not equally ranked by speakers, bearing in mind that naturalistic language learning proceeds through attempts to communicate and targets a particular language. Selection amounts to the compilation of the specific choices repeatedly made by speakers during their speech acts, resulting in the fact that some options become more natural and prevail over competitors that have been eliminated or marginalized (Mufwene, 2002b, 2005b, 2008).

8. It is ironic that Lefebvre's (2008) version of the RH sounds more and more like Corne's (1999) account of structures of French creoles by congruence, although Lefebvre maintains some of the same fundamental shortcomings. She suggested that features of the lexifier that had no (partial) matches in the dominant substrate languages do not appear in the structures of the relevant creoles and neither do features of the substrate languages that had no (partial) matches in the relevant lexifiers. Lefebvre argued that this accounts for the constituent-final position of the determiner la in Haitian Creole because both French and the Gbe languages have a similar determiner position; however, Saramaccan does not have this phrase-final determiner because it is not found in English. However, she overlooked the fact that Saramaccan has a constituent-initial determiner, like English. Haitian Creole, of course, lacks a phrase-initial determiner, even though precisely the same substrate languages are invoked in both cases.

9. The abbreviation DET PL corresponds to plural determiner.

10. In this context, Parkvall's (2006) claim that Haitian Creole has been evolving closer to French-contrary to the position that it has emerged by basilectalization away from French (e.g., Chaudenson, 2001; Valdman, 1977)—can be dismissed. Parkvall adduced no diachronic textual evidence for his claim, which is based on regional variation in the pronunciation of some words. Colonization appears to have occurred at a time when the metropolitan varieties were undergoing structural changes and displayed extensive internal variation. There are certainly alternative and more plausible accounts for variation in Haitian Creole, as in all creoles, that need not be associated with some decreolization as debasilectalization.

11. There have certainly been some studies that are off the mark with regard to how creoles emerged, such as that of Hudson and Eigsti (2003), which is based on the unnaturalistic process of prompting speakers to communicate in a language spoken by no one in their socioeconomic ecology, based on a Farsi vocabulary learned without an interactive context. Just like in Master, Schumann, and Sokolik (1989), which inspired this type of study, the context is admittedly disjoint from the real interactive settings in which creoles or pidgins emerged. Barkhuizen (2004) underscored the significance of social context and social factors in naturalistic SLA, precisely what should be remembered in accounts of the emergence of creoles.

12. Mather (2006) mistakenly considered these varieties to be interlanguages. Like creoles, they are outcomes of particular processes of group language appropriation under conditions that have favored their divergence from their metropolitan ancestors under substrate influence. Other than having scholastic varieties as starting points, these 
varieties also have the peculiarity of being transmitted or spread largely through guided, rather than naturalistic, acquisition. A third peculiarity is that they function as lingua francas rather than as vernaculars. In any case, like creoles, these varieties do not represent stages toward the complete or less divergent acquisition of a TL.

13. Smith $(2006,2009)$ seemed mistaken in arguing that the slaves had no motivation to learn the European language. They actually had no choice but to learn the economically dominant language, because they needed to communicate in order to adapt to the new interaction conditions. The process continued in accordance with naturalistic language evolution in the peculiar contact conditions rather than the intention of developing what Baker (1997) called a medium of interethnic communication.

14. The size of plantations is also an important factor, although not the most critical one. It is mainly the small plantation size, aside from the fact that the slaves were generally better integrated, that prevented the emergence of a creole in Brazil (Mufwene, 2008). Note that Brazil had begun sugar cane cultivation and slave labor at least 100 years before the Caribbean.

15. This is in keeping with Goodenough (1964), who aptly defined knowledge of a particular language variety as the ability to speak in a way that native speakers recognize as similar to their own.

16. Periods did emerge, especially after the mid-1750s, during which plantation owners preferred slaves from particular parts of Africa. However, this happened after the Creole slaves had already set the trend for monolingualism or dominance in the European colonial vernacular. Because the slave populations grew incrementally, it was difficult for the newcomers to exert the kind of influence sometimes attributed to them, even if they spoke the same language. As explained in Mufwene (1992a), this factor may account for why influence from the Bantu area is hard to find in Gullah, although slaves from this area constituted a significant majority of the slave population during the mid-18th century in South Carolina (Wood, 1974).

17. Lefebvre (2008) suggested that because Haitian Creole is allegedly a radical one, the slaves who created this creole had less exposure to the lexifier than in territories in which less radical creoles evolved. However, until the time of the Haitian revolution, the ecology of the emergence of Haitian Creole was probably comparable to that of Jamaican Creole with regard to the African-to-European population disproportions and to the access to the varieties spoken by the French and English colonists, respectively. Because French continued to be spoken by a small class of mulattoes and upper class blacks, who replaced the European ruling class, the main difference between postrevolution Haiti and other Caribbean Creole-speaking territories after the abolition of slavery lay fundamentally in whether there was continuous input from the later metropolitan varieties, not in whether the lexifier was no longer spoken.

18. Hybridization is apparently also the kind of approach advocated by Kouwenberg (2006, 2008, 2009), who referred to the fact that both Dutch and Kalabari Ijo must have contributed to structures of Berbice Dutch and to the multiplicity of substrate languages in the case of Jamaican Creole. However, unlike Aboh (e.g., 2006, 2009) and Mufwene (e.g., 2001, 2005a, 2008), Kouwenberg makes no mention of competition and selection, nor does she speak of hybridization per se, in the emergent creoles. DeGraff's (2002) rebuttal of the $\mathrm{RH}$ and his other forceful arguments against the claim that creoles are the world's simplest languages (DeGraff, 2001, 2005) are generally in support of congruence as the part of the explanation in the way structures of creoles have emerged.

19. Particularly significant in this scenario is who the learner interacted with-that is, which variety of the lexifier to which he or she was exposed.

20. This refers to the idea that the features of the different learners grouped together as similar are like those that family members are claimed to share. None of the features (such as fat lips) is shared by all the members, although each is shared by a different subset of them (Wittgenstein, 1953).

21. This is tantamount to what Flynn et al. (2004) called the cumulative-enhancement model of language acquisition.

\section{REFERENCES}

Aboh, E. (2005). The category P: The Kwa paradox. Linguistic Analysis, 32, 615-645. 
Aboh, E. (2006). The role of the syntax-semantics interface. In C. Lefebvre, L. White, \& C. Jourdan (Eds.), L2 acquisition and creole genesis (pp. 221-252). Amsterdam: Benjamins.

Aboh, E. (2007). Le genèse de la périphérie gauche du saramaka: Un cas d'influence du substrat? [The genesis of the left periphery in Saramaccan: A case of substrate influence?]. In K. Gadelli \& A. Zribi-Hertz (Eds.), Grammaires créoles et grammaire comparative (pp. 73-97). Paris: Presses Universitaires de Vincennes.

Aboh, E. (2009). Competition and selection: That's all! In E. Aboh \& N. Smith (Eds.), Complex processes in new languages (pp. 317-344). Amsterdam: Benjamins.

Aboh, E., \& Smith, N. (Eds.). (2009). Complex processes in new languages. Amsterdam: Benjamins.

Alleyne, M. C. (1980). Comparative Afro-American. Ann Arbor, MI: Karoma.

Ansaldo, U. (2009). Contact languages: Ecology and evolution in Asia. New York: Cambridge University Press.

Ansaldo, U., Matthews, S., \& Lim, L. (Eds.). (2007). Deconstructing creole. Amsterdam: Benjamins.

Arends, J. (1989). Syntactic developments in Sranan. Unpublished doctoral dissertation, University of Nijmegen, Nijmegen, The Netherlands.

Arends, J. (Ed.). (1995). The early stages of creolization. Amsterdam: Benjamins.

Arends, J. (2009). A demographic perspective on creole formation. In S. Kouwenberg \& J. V. Singler (Eds.), The handbook of pidgin and creole studies (pp. 309-331). New York: Wiley.

Baker, P. (1990). Off target? Journal of Pidgin and Creole Languages, 5, 107-119.

Baker, P. (1993). Assessing the African contribution to French-based creoles. In S. S. Mufwene (Ed.), Africanisms in Afro-American language varieties (pp. 123-155). Athens: University of Georgia Press.

Baker, P. (1995). Some developmental inferences from the historical studies of pidgins and creoles. In J. Arends (Ed.), The early stages of creolization (pp. 1-24). Amsterdam: Benjamins.

Baker, P. (1996). Australian and Melanesian PE and the fellows in between. In P. Baker \& A. Syea (Eds.), Changing meanings, changing functions: Papers relating to grammaticalization in contact languages (pp. 243-258). London: University of Westminster Press.

Baker, P. (1997). Directionality in pidginization and creolization. In A. K. Spears \& D. Winford (Eds.), The structure and status of pidgins and creoles (pp. 91-109). Amsterdam: Benjamins.

Bambgose, A. (1992). Standard English in Nigeria: Issues of identification. In B. Kachru (Ed.), The other tongues: English across cultures (pp. 140-161). Urbana: University of Illinois Press.

Bambgose, A. (1998). Torn between the norms: Innovations in world Englishes. World Englishes, 17, 1-14.

Barkhuizen, G. (2004). Social influence on language learning. In A. Davies \& C. Elder (Eds.), The handbook of applied linguistics (pp. 552-575). Oxford: Blackwell.

Barthélemy, G. (2000). Créoles: Bossales-Conflit en Haïti [Creoles: Bozals-Conflict in Haiti]. Petit-Bourg, Guadeloupe: Ibis Rouge Editions.

Becker, A., \& Veenstra, T. (2003). The survival of inflectional morphology in French-related creoles. Studies in Second Language Acquisition, 25, 283-306.

Bickerton, D. (1981). Roots of language. Ann Arbor, MI: Karoma.

Bickerton, D. (1984). The language bioprogram hypothesis. Behavioral and Brain Sciences, $7,173-221$.

Bickerton, D. (1999). How to acquire language without positive evidence: What acquisitionists can learn from creoles. In M. DeGraff (Ed.), Language creation and language change: Creolization, diachrony, and development (pp. 49-74). Cambridge, MA: MIT Press.

Bolinger, D. (1973). Getting the words in. In R. McDavid, Jr. \& A. Duckert (Eds.), Lexicography in English (pp. 8-13). New York: New York Academy of Science.

Chaudenson, R. (1979). Les créoles français [French creoles]. Paris: Nathan.

Chaudenson, R. (1992). Des îles, des hommes, des langues [About islands, people, and languages]. Paris: L'Harmattan.

Chaudenson, R. (2001). Creolization of language and culture. London: Routledge. 
Chaudenson, R. (2003). La créolisation: Théorie, applications, implications [Creolization: Theory, applications, implications]. Paris: L'Harmattan.

Chomsky, N. (1986). Knowledge of language: Its nature, origin, and use. New York: Praeger.

Clements, J. C. (2009). The linguistic legacy of Spanish and Portuguese. New York: Cambridge University Press.

Cook, V. (1993). Linguistics and second language acquisition. New York: St. Martin's Press.

Corne, C. (1999). From French to Creole: The development of new vernaculars in the French colonial world. London: University of Westminster Press.

Deacon, T. W. (1997). The symbolic species: The co-evolution of language and the brain. New York: W.W. Norton \& Co.

DeGraff, M. (1993). A riddle on negation in Haitian. Probus, 5, 63-93.

DeGraff, M. (1999). Creolization, language change, and language acquisition: A prolegomenon. In M. DeGraff (Ed.), Language creation and language change: Creolization, diachrony, and development (pp. 1-46). Cambridge, MA: MIT Press.

DeGraff, M. (2001). On the origin of creoles: A Cartesian critique of neo-Darwinian linguistics. Linguistic Typology, 5, 213-310.

DeGraff, M. (2002). Relexification: A reevaluation. Anthropological Linguistics, 44, 321-414.

DeGraff, M. (2003). Against creole exceptionalism: Discussion note. Language, 79, 391410.

DeGraff, M. (2005). Linguists' most dangerous myth: The fallacy of Creole exceptionalism. Language in Society, 34, 533-591.

DeGraff, M. (2009). Language acquisition in creolization and, thus, language change: Some Cartesian-uniformitarian boundary conditions. Language and Linguistics Compass, $3 / 4,888-971$.

Dillard, J. L. (1970). Principles in the history of American English: Paradox, virginity and cafeteria. Florida FL Reporter, 8, 32-33.

Dooley, K. J. (1997). A complex adaptive systems model of organization change. Nonlinear Dynamics, Psychology, and Life Sciences, 1, 69-97.

Dörnyei, Z., \& Skehan, P. (2003). Individual differences in second language learning. In C. J. Doughty \& M. H. Long (Eds.), The handbook of second language acquisition (pp. 588-630). Oxford: Blackwell.

Douzet, F. (2004). Le cauchemar hispanique de Samuel Huntington [Samuel Huntingon's Hispanic nightmare]. Hérodote: Revue de Géographie et de Géopolitique, 115, 31-51.

Dunn, R. S. (1972). Sugar and slaves: The rise of the planter class in the English West Indies, 1624-1713. Chapel Hill: The University of North Carolina Press.

Ellis, R. (1994). The study of second language acquisition. Oxford: Oxford University Press.

Ellis, R. (2004). Individual differences in second language learning. In A. Davies \& C. Elder (Eds.), The handbook of applied linguistics (pp. 524-551). Oxford: Blackwell.

Fattier, D. (2000). Contribution à l'étude de la genèse d'un créole: L'atlas linguistique d'Haïti, cartes et commentaires [A contribution to the study of the genesis of a creole: The linguistic atlas of Haiti, maps and commentaries]. Villeneuve d'Ascq, France: Presses Universitaires de Septentrion.

Fayer, J. (2003). African interpreters in the Atlantic slave trade. Anthropological Linguistics, 45, 281-295.

Flynn, S., Foley, C., \& Vinnitskaya, I. (2004). The cumulative-enhancement model of language acquisition: Comparing adults' and children's patterns of development in first, second and third language acquisition of relative clauses. International Journal of Multilingualism, 1, 3-16.

Gabriele, A., \& Martohardjono, G. (2005). Investigating the role of transfer in the L2 acquisition of aspect. In L. Dekydtspotter, R. A. Sprouse, \& A. Liljestrand (Eds.), Proceedings of Generative Approaches to Second Language Acquisition (GASLA) 7 (pp. 96-110). Somerville, MA: Cascadilla Press.

Giacomi, A., Stoffel, H., \& Véronique, D. (2000). Appropriation du français par des Marocains arabophones à Marseilles [The appropriation of French by Arabic-speaking Morrocans in Marseilles]. Aix-en-Provence, France: Publications de l'Université de Provence.

Gilman, C. (1986). African areal characteristics: Sprachbund, not substrate? Journal of Pidgin and Creole Languages, 1, 33-50.

Goodenough, W. H. (1964). Cultural anthropology in linguistics. In D. Hymes (Ed.), Language in culture and society (pp. 36-39). New York: Harper \& Row. 
Hagège, C. (1993). The language builder: An essay on the human signature in linguistic morphogenesis. Amsterdam: Benjamins.

Håkansson, G., Pienemann, M., \& Sayehli, S. (2002). Transfer and typological proximity in the context of second language processing. Second Language Research, 18, 250-273.

Hancock, I. (1993). Creole language provenance and the African component. In S. S. Mufwene (Ed.), Africanisms in Afro-American language varieties (pp. 182-191). Athens: University of Georgia Press.

Hansen Edwards, J. G., \& Zampini, M. I. (Eds.). (2008). Phonology and second language acquisition. Amsterdam: Benjamins.

Helms-Park, R. (2003). Transfer in SLA and creoles: The implications of causative serial verbs in the interlanguages of Vietnamese ESL learners. Studies in Second Language Acquisition, 25, 211-244.

Holm, J. (1988). Pidgins and Creoles: Vol. 1. Theory and structure. New York: Cambridge University Press.

Hudson, C. L., \& Eigsti, I.-M. (2003). The lexical competence hypothesis: A cognitive account of the relationship between vernacularization and grammatical expansion in creolization. Journal of Pidgin and Creole Languages, 18, 1-79.

Jourdan, C. (2009). Complexification or regularization of paradigms: The case of prepositional verbs in Solomon Islands Pijin. In E. Aboh \& N. Smith (Eds.), Complex processes in new languages (pp. 159-170). Amsterdam: Benjamins.

Kachru, B. B. (1996). English in South Asia. In R. Burchfield (Ed.), The Cambridge history of the English language: Vol. 5. English in Britain and overseas-Origins and development (pp. 497-553). New York: Cambridge University Press.

Kachru, B. B. (2005). Asian Englishes: Beyond the canon. Hong Kong: Hong Kong University Press.

Kachru, Y., \& Nelson, C. L. (2006). World Englishes in Asian contexts. Hong Kong: Hong Kong University Press.

Keesing, R. M. (1988). Melanesian Pidgin and the Oceanic substrate. Stanford, CA: Stanford University Press.

Keller, R. (1994). On language change: The invisible hand in language. London: Routledge.

Klein, W., \& Perdue, C. (1992). Utterance structure: Developing grammar again. Amsterdam: Benjamins.

Kouwenberg, S. (1994). A grammar of Berbice Dutch Creole. Berlin: Mouton de Gruyter.

Kouwenberg, S. (2006). L1 transfer and the cut-off point for L2 acquisition processes in creole formation. In C. Lefebvre, L. White, \& C. Jourdan (Eds.), L2 acquisition and creole genesis (pp. 205-219). Amsterdam: Benjamins.

Kouwenberg, S. (2008). The problem of multiple substrates: The case of Jamaican Creole. In S. Michaelis (Ed.), Roots of creole structures: Weighing the contributions of substrates and superstrates (pp. 1-27). Amsterdam: Benjamins.

Kouwenberg, S. (2009). The invisible hand in creole genesis: Reanalysis in the formation of Berbice Dutch. In E. Aboh \& N. Smith (Eds.), Complex processes in new languages (pp. 115-158). Amsterdam: Benjamins.

Kouwenberg, S., \& Patrick, P. L. (Eds.). (2003). Reconsidering the role of SLA in pidginization and creolization. [Special issue]. Studies in Second Language Acquisition, 25(2).

Kouwenberg, S., \& Singler, J. V. (Eds.). (2009). The handbook of pidgin and creole studies. New York: Wiley.

Kretzschmar, W. A., \& Tamasi, S. (2003). Distributional foundations for a theory of language change. World Englishes, 22, 377-401.

Labov, W. (1998). Co-existent systems in African-American vernacular English. In S. S. Mufwene, J. R. Rickford, G. Bailey, \& J. Baugh (Eds.), African-American English: Structure, history, and use (pp. 110-153). London: Routledge.

Lass, R. (1997). Historical linguistics and language change. New York: Cambridge University Press.

Lantolf, J. P., \& Thorne, S. L. (2006). Sociocultural theory and the genesis of second language development. Oxford: Oxford University Press.

Leather, J., \& van Dam, J. (Eds.). (2003). Ecology of language acquisition. Dordrecht: Kluwer.

Lefebvre, C. (1998). Creole genesis and the acquisition of grammar: The case of Haitian Creole. New York: Cambridge University Press.

Lefebvre, C. (2004). Issues in the study of Pidgin and Creole languages. Amsterdam: Benjamins. 
Lefebvre, C. (2008). On the principled nature of the respective contributions of substrate and superstrate languages to a creole's lexicon. In S. Michaelis (Ed.), Roots of creole structures: Weighing the contributions of substrates and superstrates (pp. 197-223). Amsterdam: Benjamins.

Lefebvre, C., White, L., \& Jourdan, C. (2006a). Introduction. In C. Lefebvre, L. White, \& C. Jourdan (Eds.), L2 acquisition and creole genesis (pp. 1-14). Amsterdam: Benjamins.

Lefebvre, C., White, L., \& Jourdan, C. (Eds.). (2006b). L2 acquisition and creole genesis. Amsterdam: Benjamins.

Lopez, D., \& Estrada, V. (2004). La menace hispanique: L'espagnol menace-t-il l'anglais aux Etats-Unis? [The Hispanic threat: Is Spanish threatening English in the United States?]. Hérodote: Revue de Géographie et de Géopolitique, 115, 53-61.

Lumsden, J. S. (1999). Language acquisition and creolization. In M. DeGraff (Ed.), Language creation and language change (pp. 129-157). Cambridge, MA: MIT Press.

Martohardjono, G., \& Flynn, S. (1995). Is there an age factor for Universal Grammar? In D. Singleton \& Z. Lengyel (Eds.), The age factor in second language acquisition (pp. 135-153). Clevedon, UK: Multilingual Matters.

Master, P., Schumann, J., \& Sokolik, M. E. (1989). The experimental creation of a pidgin language. Journal of Pidgin and Creole Languages, 4, 37-63.

Mather, P. A. (2006). Second language acquisition and creolization: Same (i-) processes, different (e-) results. Journal of Pidgin and Creole Languages, 21, 231-274.

McCawley, J. D. (1976). Some ideas not to live by. Die neueren Sprachen, 75, 151-165.

McWhorter, J. H. (1998). Identifying the creole prototype: Vindicating a typological class. Language, 74, 788-818.

Meillet, A. (1906). L'état actuel des études de linguistique générale [The current state of studies in general linguistics]. Revue des Idées, 3, 296-308.

Meillet, A. (1929). Le développement des langues [Language development]. In J. Chevalier (Ed.), Continu et discontinu (pp. 119-131). Paris: Bloud \& Gay.

Michaelis, S. (Ed.). (2008a). Roots of creole structures: Weighing the contributions of substrates and superstrates. Amsterdam: Benjamins.

Michaelis, S. (2008b). Vallency in Seychelles Creole: Where do they come from? In S. Michaelis (Ed.), Roots of creole structures: Weighing the contributions of substrates and superstrates (pp. 225-251). Amsterdam: Benjamins.

Mikulecky, D. C. (2001). The emergence of complexity: Science coming of age or science growing old? Computers and Chemistry, 25, 341-348.

Mufwene, S. S. (1985). The linguistic significance of African proper names in Gullah. New West Indian Guide, 59, 146-166.

Mufwene, S. S. (1986). The universalist and substrate hypotheses complement one another. In P. Muysken \& N. Smith (Eds.), Substrata versus universals in creole genesis (pp. 129-162). Amsterdam: Benjamins.

Mufwene, S. S. (1990). Transfer and the substrate hypothesis in creolistics. Studies in Second Language Acquisition, 12, 1-23.

Mufwene, S. S. (1991). [Review of the book Pidgins and Creoles]. Language, 67, 380-387.

Mufwene, S. S. (1992a). Africanisms in Gullah: A re-examination of the issues. In J. Hall, N. Doane, \& D. Ringler (Eds.), Old English and new: Essays in language and linguistics in honor of Frederic G. Cassidy (pp. 156-182). New York: Garland Press.

Mufwene, S. S. (1992b). Why grammars are not monolithic. In D. Brentari, G. Larson, \& L. A. MacLeod (Eds.), The joy of grammar: A festschrift in honor of James D. McCawley (pp. 225-250). Amsterdam: Benjamins.

Mufwene, S. S. (1993a). African substratum: Possibility and evidence-A discussion of Alleyne's and Hancock's papers. In S. S. Mufwene (Ed.), Africanisms in Afro-American language varieties (pp. 192-208). Athens: University of Georgia Press.

Mufwene, S. S. (Ed.). (1993b). Africanisms in Afro-American language varieties. Athens: University of Georgia Press.

Mufwene, S. S. (1996). The founder principle in creole genesis. Diachronica, 13, 115168.

Mufwene, S. S. (1997). Jargons, pidgins, creoles, and koinés: What are they? In A. K. Spears \& D. Winford (Eds.), The structure and status of pidgins and creoles (pp. 35-70). Amsterdam: Benjamins. 
Mufwene, S. S. (2000). Creolization is a social, not a structural, process. In I. NeumannHolzschuh \& E. W. Schneider (Eds.), Degrees of restructuring in creole languages (pp. 65-84). Amsterdam: Benjamins.

Mufwene, S. S. (2001). The ecology of language evolution. New York: Cambridge University Press.

Mufwene, S. S. (2002a). Analogs anywhere: The flow of highway traffic and language evolution. In S. S. Mufwene \& S. Neuvel (Eds.), Contemporary Linguistics 3 (pp. 39-57). Department of Linguistics, University of Chicago, Chicago.

Mufwene, S. S. (2002b). Competition and selection in language evolution. Selection, 3, 45-56.

Mufwene, S. S. (2004). Multilingualism in linguistic history: Creolization and indigenization. In T. Bhatia \& W. Richie (Eds.), Handbook of bilingualism (pp. 460-488). Oxford: Blackwell.

Mufwene, S. S. (2005a). Créoles, écologie sociale, évolution linguistique [Creoles, social ecology, language evolution]. Paris: L'Harmattan.

Mufwene, S. S. (2005b). Language evolution: The population genetics way. In G. Hauska (Ed.), Gene, Sprachen, und ihre Evolution (pp. 30-52). Regensburg, Germany: Universitaetsverlag Regensburg.

Mufwene, S. S. (2008). Language evolution: Contact, competition and change. New York: Continuum.

Mufwene, S. S. (2009a). The indigenization of English in North America. In T. Hoffmann \& L. Siebers (Eds.), World Englishes: Problems, properties, prospects-Selected papers from the 13th IAWE Conference (pp. 353-368). Amsterdam: Benjamins.

Mufwene, S. S. (2009b). Postscript: Restructuring, hybridization, and complexity in language evolution. In E. Aboh \& N. Smith (Eds.), Complex processes in new languages (pp. 367-400). Amsterdam: Benjamins.

Neumann-Holzschuh, I. (2008). A la recherche du "superstrat": What North American French can and cannot tell us about the input to creolization. In S. Michaelis (Ed.), Roots of creole structures: Weighing the contributions of substrates and superstrates (pp. 357-383). Amsterdam: Benjamins.

Odlin, T. (2003). Language ecology and the Columbian exchange. In B. Joseph, J. Destafano, N. Jacobs, \& I. Lehiste (Eds.), When languages collide: Perspectives on language conflict, language competition, and language coexistence (pp. 71-94). Columbus: Ohio State University Press.

Parkvall, M. (2000a). Out of Africa: African influences in Atlantic creoles. London: Battlebridge.

Parkvall, M. (2000b). Reassessing the role of demographics in language restructuring. In I. Neumann-Holzschuh \& E. W. Schneider (Eds.), Degrees of restructuring in creole languages (pp. 185-213). Amsterdam: Benjamins.

Parkvall, M. (2006). Was Haitian ever more like French? In A. Deumert \& S. Durrleman (Eds.), Structure and variation in language contact (pp. 315-335). Amsterdam: Benjamins.

Patrick, P. L. (1999). Urban Jamaican creole: Variation in the mesolect. Amsterdam: Benjamins.

Perdue, C. (1995). L'acquisition du français et de l'anglais par des adultes: Former des énoncés [The acquisition of French and English by adults: Formation of utterances]. Paris: CNRS Editions.

Pienemann, M. (2003). Language processing capacity. In C. J. Doughty \& M. H. Long (Eds.), The handbook of second language acquisition (pp. 678-714). Oxford: Blackwell.

Plag, I. (2008). Creoles as interlanguages: Syntactic structures. Journal of Pidgin and Creole Languages, 23, 307-328.

Plag, I. (2009). Creoles as interlanguages: Phonology. Journal of Pidgin and Creole Languages, 24, 119-138.

Roberts, S. J. (1998). The role of diffusion in the genesis of Hawaiian Creole. Language, 74, $1-39$.

Roberts, S. J. (2005). The emergence of Hawai ' $i$ Creole English in the early 20th century: The sociohistorical context of creole genesis. Unpublished doctoral dissertation, Stanford University, Stanford, CA.

Saussure, F. de (1916). Cours de linguistique générale [Course in general linguistics] (C. Bally, A. Sechehaye, \& A. Riedlienger, Eds.). Paris: Payot.

Schneider, E. W. (2007). Post-colonial Englishes: The dynamics of language diffusion. New York: Cambridge University Press.

Schumann, J. H. (1978). The relationship of pidginization, creolization and decreolization to second language acquisition. Language Learning, 28, 267-379. 
Schwartz, B. D. (2006). Transfer and bootstrapping. In C. Lefebvre, L. White, \& C. Jourdan (Eds.), L2 acquisition and creole genesis (pp. 183-204). Amsterdam: Benjamins.

Shackleton, R. (2005). English-American speech relationships: A quantitative approach. Journal of English Linguistics, 33, 99-160.

Siegel, J. (2006). Links between SLA and creole studies: Past and present. In C. Lefebvre, L. White, \& C. Jourdan (Eds.), L2 acquisition and creole genesis (pp. 15-46). Amsterdam: Benjamins.

Siegel, J. (2008a). The emergence of pidgin and creole languages. Oxford: Oxford University Press.

Siegel, J. (2008b). In praise of the cafeteria principle: Language mixing in Hawai'i Creole. In S. Michaelis (Ed.), Roots of creole structures: Weighing the contributions of substrates and superstrates (pp. 59-82). Amsterdam: Benjamins.

Siegel, J. (2009). Pidgins/creoles and second language acquisition. In S. Kouwenberg \& J. V. Singler (Eds.), The handbook of pidgin and creole studies (pp. 189-218). New York: Wiley.

Singler, J. V. (1988). The homogeneity of the substrate as a factor in pidgin/creole genesis. Language, 64, 27-51.

Singler, J. V. (1995). The demographics of creole genesis in the Caribbean: A comparison of Martinique and Haiti. In J. Arends (Ed.), The early stages of creolization (pp. 203232). Amsterdam: Benjamins.

Singler, J. V. (1996). Theories of creole genesis, sociohistorical considerations, and the evaluation of evidence: The case of Haitian Creole and the relexification hypothesis. Journal of Pidgin and Creole Languages, 11, 185-230.

Singler, J. V. (2009). The sociohistorical context of creole genesis. In S. Kouwenberg \& J. V. Singler (Eds.), The handbook of pidgin and creole studies (pp. 332-358). New York: Wiley.

Smith, N. (2006). Very rapid creolization in the framework of the restricted motivation hypothesis. In C. Lefebvre, L. White, \& C. Jourdan (Eds.), L2 acquisition and creole genesis (pp. 49-65). Amsterdam: Benjamins.

Smith, N. (2009). Simplification of a complex part of grammar or not? What happened to Kikoongo nouns in Saramaccan? In E. Aboh \& N. Smith (Eds.), Complex processes in new languages (pp. 51-73). Amsterdam: Benjamins.

Sprouse, R. A. (2006). Second language acquisition and creole genesis. In C. Lefebvre, L. White, \& C. Jourdan (Eds.), L2 acquisition and creole genesis (pp. 169-181). Amsterdam: Benjamins.

Thomason, S. G. (2001). Language contact: An introduction. Washington, DC: Georgetown University Press.

Thomason, S. G., \& Kaufman, T. (1988). Language contact, creolization, and genetic linguistics. Berkeley: University of California Press.

Turner, L. D. (1949). Africanisms in the Gullah dialect. Chicago: University of Chicago Press.

Valdman, A. (1977). Créolisation sans pidgin: Le système des déterminants du nom dans les parlers franco-créoles [Creolization without pidgins: The noun determiner system in franco-creoles]. In J. M. Meisel (Ed.), Langues en contact: Pidgins, Creoles (pp. 105136). Tübingen: Gunter Narr Verlag.

Véronique, D. (1994). Naturalistic adult acquisition of French as L2 and French-based creole genesis compared: Insights into creolization and language change. In D. Adone \& I. Plag (Eds.), Creolization and language change (pp. 117-137). Tübingen: Niemeyer.

Wekker, H. (1996). Creolization and the acquisition of English as a second language. In H. Wekker (Ed.), Creole languages and language acquisition (pp. 139-149). Berlin: Mouton de Gruyter.

Winford, D. (2003). An introduction to contact linguistics. Oxford: Blackwell.

Wittgenstein, L. (1953). Philosophical investigations. Oxford: Blackwell.

Wolfram, W. (2000). On the construction of vernacular dialect norms. In A. Okrent \& J. Boyle (Eds.), Papers from the 36th Meeting of the Chicago Linguistic Society: Vol. 2. The Panels (pp. 335-358). Chicago: Chicago Linguistic Society.

Wolfram, W. (2008). American English since 1865. In H. Momma \& M. Motto (Eds.), A companion to the history of the English language (pp. 263-273). New York: Wiley.

Wood, P. (1974). Black majority: Negroes in colonial South Carolina from 1670 through the Stono rebellion. New York: Alfred A. Knopf. 